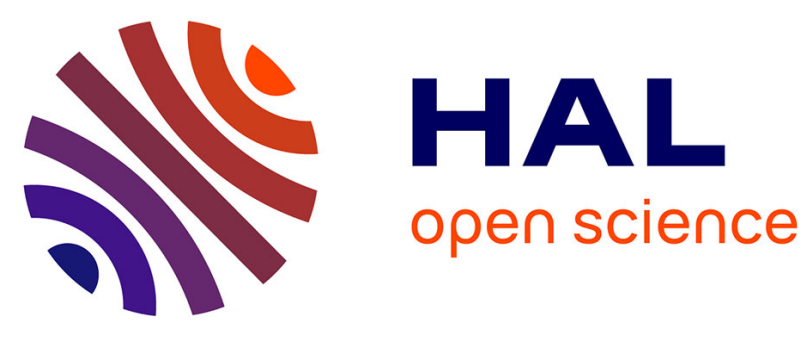

\title{
Quantitative analysis of climate versus human impact on sediment yield since the Lateglacial : the Sarliève paleolake catchment (France)
}

Jean-Jacques Macaire, Agathe Fourmont, Jacqueline Argant, Jean-Gabriel

Bréhéret, Florent Hinschberger, Frédéric Trément

\section{To cite this version:}

Jean-Jacques Macaire, Agathe Fourmont, Jacqueline Argant, Jean-Gabriel Bréhéret, Florent Hinschberger, et al.. Quantitative analysis of climate versus human impact on sediment yield since the Lateglacial: the Sarliève paleolake catchment (France). The Holocene, 2010, 20 (4), pp.497-516. 10.1177/0959683609355181 . halshs-01838324

\section{HAL Id: halshs-01838324 \\ https://shs.hal.science/halshs-01838324}

Submitted on 5 Sep 2018

HAL is a multi-disciplinary open access archive for the deposit and dissemination of scientific research documents, whether they are published or not. The documents may come from teaching and research institutions in France or abroad, or from public or private research centers.
L'archive ouverte pluridisciplinaire HAL, est destinée au dépôt et à la diffusion de documents scientifiques de niveau recherche, publiés ou non, émanant des établissements d'enseignement et de recherche français ou étrangers, des laboratoires publics ou privés. 


\title{
Quantitative analysis of climate versus human impact on sediment yield since the Lateglacial: The Sarliève palaeolake catchment (France)
}

The Holocene 20(4) 497-516

(C) The Author(s) 2010

Reprints and permission:

sagepub.co.uk/journalsPermissions.nav DOI: $10.1177 / 0959683609355181$

http://hol.sagepub.com

(9SAGE

\author{
Jean-Jacques Macaire, ${ }^{1}$ Agathe Fourmont, ${ }^{1}$ Jacqueline Argant, ${ }^{2}$ Jean-Gabriel \\ Bréhéret, ${ }^{1}$ Florent Hinschberger ${ }^{1}$ and Frédéric Trément ${ }^{3}$
}

\begin{abstract}
Minimum rates of solid (SSY) and dissolved (DSY) sediment yield (SY) were evaluated in $\mathrm{t} / \mathrm{km}^{2}$ per yr from sediments stored in the Sarliève palaeolake (French Massif Central) for seven phases of the Lateglacial and Holocene up to the seventeenth century. The catchment $\left(29 \mathrm{~km}^{2}\right)$, mainly formed of limestones and marls, is located in an area rich in archaeological sites in the Massif Central. The respective impacts of human activities and climate on SY were compared by quantification of human settlements through archaeological survey and palynological data. During the Lateglacial and early Holocene up to about $7500 \mathrm{yr}$ cal. BP, variations in SSY and DSY rates were mainly related to climate change with higher rates during colder periods (Younger Dryas and Preboreal) and lower rates during warmer periods (Bölling-Alleröd and Boreal). However, CF1 tephra fallout induced a sharp increase in SY during the Alleröd. During the middle and late Holocene after $7500 \mathrm{yr}$ cal. BP, SSY and DSY greatly increased (by factors of 6.5 and 2.8 , respectively), particularly during the Final Neolithic at about $5300 \mathrm{yr}$ cal. BP when the climate became cooler and more humid. After this date, at least $75 \%$ of the SSY increase and more than $90 \%$ of the DSY increase resulted from human activities, but SSY rates showed little variation during Protohistoric and Historic Times up to the seventeenth century. SSY and DSY rates and DSY/SSY ratio indicate that catchment soils began to form during the Lateglacial and Preboreal, thickened considerably during the Boreal and Atlantic, finally thinning (rejuvenation) mainly as the result of human-induced erosion during the sub-Boreal and sub-Atlantic. Increased mechanical erosion during the late Holocene also induced an increase in chemical erosion.
\end{abstract}

\section{Keywords}

archaeological survey, climate-change impact, French Massif Central, Holocene, land-use impact, Lateglacial, palaeolake, soil erosion, solid and dissolved sediment yield

\section{Introduction}

Current earth surface sediment yield, mainly assessed from solid and dissolved fluxes in rivers, is highly dependent on human activities whose impact is difficult to quantify compared with that of natural factors, particularly climate (e.g. Judson and Ritter, 1964; Douglas, 1967; Milliman and Syvitski, 1992; Ludwig and Probst, 1998). There are three main questions regarding human impact on sediment yield (Hooke, 2000; Ruddiman, 2003; Wilkinson, 2005). (1) When did it start? (2) How did it evolve? (3) What was its intensity? These questions can be investigated by assessing pre-human and syn-human sediment yields, through studying sedimentary archives stored in favourable basins, particularly lakes (e.g. Campy et al., 1994; Macaire et al., 1997; Dearing and Jones, 2003). Many studies have shown a trend of increasing sediment yield over several thousand years in populated areas (e.g. Zolitschka, 1998; Bichet et al., 1999; Dearing and Jones, 2003). These studies mainly concern solid sediment yield deduced from quantification of detrital sediment stores. Dissolved yield has been more rarely quantified (Einsele and Hinderer, 1998; Gay and Macaire, 1999), although chemical erosion has been found to be of major importance in some lithological or bioclimatic environments (Meybeck, 1987; Berner and Berner, 1987). There is very little information about chemical sediment flux as compared to the detrital fraction because the precipitated fraction of lake sediments is often difficult to differentiate and quantify. In a catchment of given physiography, the ratio of dissolved versus solid yield depends considerably on runoff and thus on vegetation related to climate and recently to human activities (Walling and Webb, 1986).

An overall increasing sediment yield over the last few thousand years, with some intermittent periods of lower yields, is generally interpreted as the result of human activities (e.g. Zolitschka, 1998; Hooke, 2000; Edwards and Whittington, 2001). This interpretation is based on various proxies of anthropogenic impact. The most usual human-activity proxy is the palynological

\footnotetext{
${ }^{1}$ Université François-Rabelais de Tours, CNRS/INSU, Université d'Orléans, UMR-CNRS 6113 ISTO, France

${ }^{2}$ Université Claude Bernard Lyon I, UMR 6636, France

${ }^{3}$ Université de Clermont-Ferrand, EA 1001, France
}

Received 12 April 2009; revised manuscript accepted 24 October 2009

\section{Corresponding author:}

Jean-Jacques Macaire, Université François-Rabelais de Tours, CNRS/ INSU, Université d'Orléans, UMR 6113 ISTO, Faculté des Sciences et Techniques, Avenue Monge, 37200 Tours, France Email: jean-jacques.macaire@univ-tours.fr 


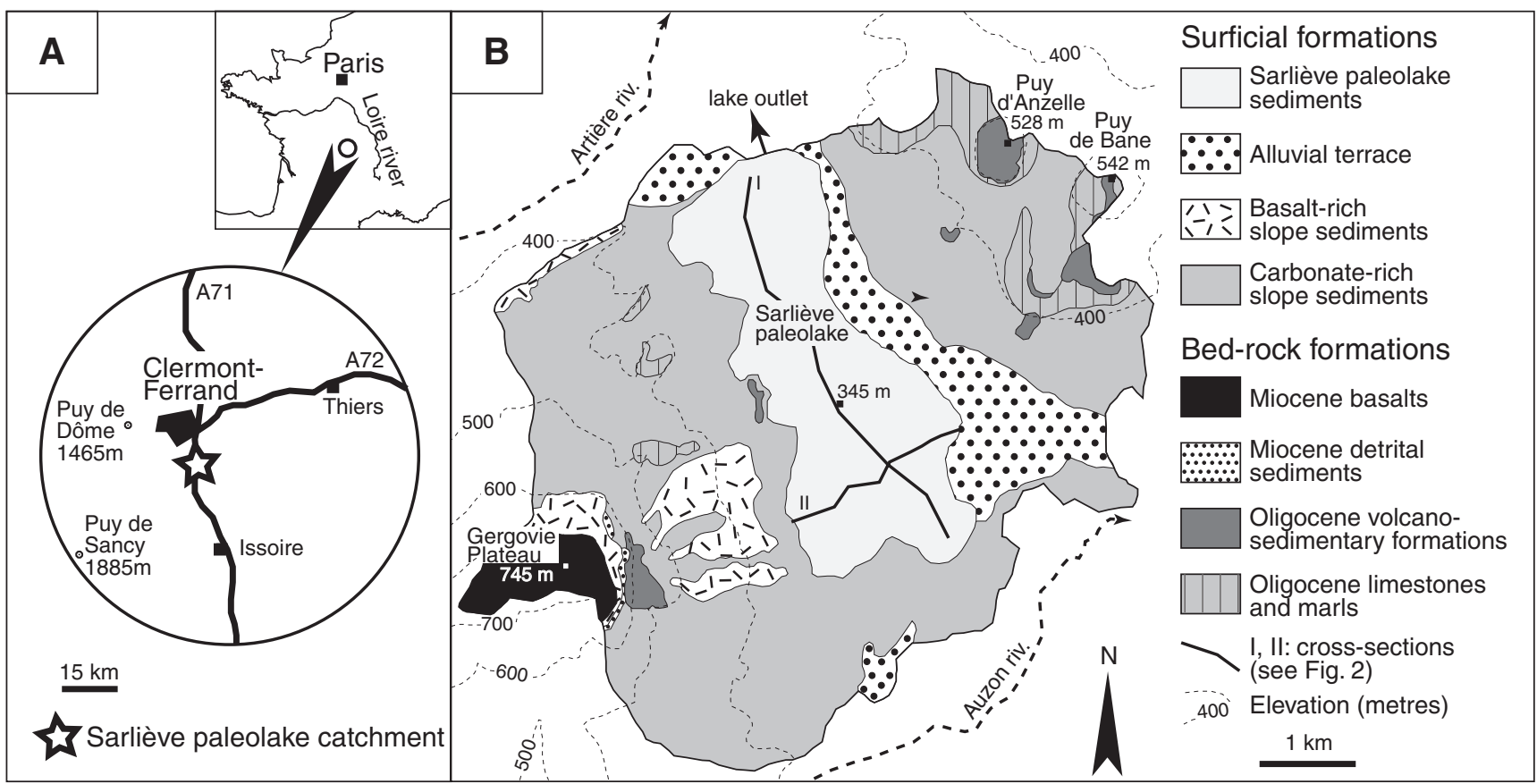

Figure 1. Location (A) and main physiographical characteristics (B) of the Sarliève catchment

record which provides indirect information (deforestation, cereal cultivation, pasture, etc.) from vegetation. Evidence of early human presence is generally provided directly by artefacts, building structures, etc., but data are often very sparse and were not determined in a systematic manner, and so make it impossible to quantify the density of human occupation and compare it with sediment yields at different periods.

The aim of this work was thus: (1) to quantify sediment yield (SY) from lacustrine sediment stores for different periods before and during human impact since the Lateglacial, distinguishing rates of solid sediment yield (SSY) from dissolved sediment yield (DSY), (2) to compare these rates with quantitative data of human settlement (age, density and location of archaeological sites) from detailed and systematic archaeological surveys in the lake catchment; intensity and type of human activities were evaluated from analysis of pollen grains in lacustrine sediments, and (3) finally to evaluate the land surface lowering by catchment-soil erosion which contributed to the sediment yield.

The studied area is a small lacustrine catchment in the centre of France. Lacustrine deposits, stored since the Lateglacial, have been the subject of detailed sedimentological, palaeohydrological and geophysical studies (Bréhéret et al., 2003, 2008; Fourmont, 2005; Fourmont et al., 2006, 2009; Hinschberger et al., 2006). This catchment, located in a major site of French history ('oppidum de Gergovie'), contains considerable evidence of human settlement since the Neolithic and has been the subject of systematic archaeological surveys (Trément et al., 2005, 2006, 2007a, b).

\section{The Sarliève palaeolake and its catchment: geological setting, sedimentological and palaeohydrological evolution}

Here, and in the following sections, all ages are given in calibrated years BP. Calibration of radiocarbon ages is based on the
INTCAL04 data set. The 'Marais de Sarliève' is an ancient lake (surface area: $5 \mathrm{~km}^{2}$ maximum, altitude: approximately $345 \mathrm{~m}$ ), formed a little before $13700 \mathrm{yr}$ cal. BP (Fourmont et al., 2006). It is located in the Auvergne region, $10 \mathrm{~km}$ southwest of ClermontFerrand in the Limagne rift $(x=663780 \mathrm{~m} ; y=2082180 \mathrm{~m}$ in the Lambert Conformal Conic system; Figure 1A). The origin of the lacustrine depression is probably tectonic (Ballut, 2000; Trément et al., 2007b; Fourmont et al., 2009); it can only be drained by evaporation or via the outlet located at the northeastern end of the catchment (Figure 1B). The depression filled with sediments until it was drained by humans during the seventeenth century (Fournier, 1996); it is bordered on the north and east by alluvial terraces. The catchment (total surface area: $29 \mathrm{~km}^{2}$ ) is mainly composed of Oligocene marls and limestones, partly dolomitic and sometimes gypsum-rich, with small outcrops of basaltic rocks on the surrounding hills up to $745 \mathrm{~m}$ (Jeambrun et al., 1973). Bed-rock is generally covered with superficial formations derived from Oligocene carbonated rock (Figure 1B). This area is currently characterized by a strong continental climate: mean annual rainfall is less than $600 \mathrm{~mm}$ and mean annual temperature is approximately $11^{\circ} \mathrm{C}\left(\min 4{ }^{\circ} \mathrm{C}, \max 21^{\circ} \mathrm{C}\right) \quad($ Kessler and Chambraud, 1986).

Lacustrine sediments, studied through deep pits and core drillings, consist of delta and basin deposits (Bréhéret et al., 2003, 2008; Fourmont et al., 2006, 2009). Delta deposits, 4-5 m thick (D1 to D7, Figure 2A), are located in the median part of the depression and comprise several units. From base to top these are: D1, beige to greenish carbonated clayey-silts (CS); T1, black pyroclastic sands; D2, several metres-thick deltaic sands composed of alternating layers of dark tephric sand and light-coloured more carbonated sandy-silt; D3, sandy colluvium topped by a palaeosoil; D4, ochre sands; D5, homogeneous greenish calcitic CS including a thin, pale pink tephra T2; D6, charcoal-rich black calcitic CS; D7, greenish-grey to brown calcitic CS. Basin deposits, 5-6 m thick, observed in the north and south lobes of the depression (B1 to B6, Figure 2A, B), are made up of clayey-silty 


\section{A - Cross-section I}

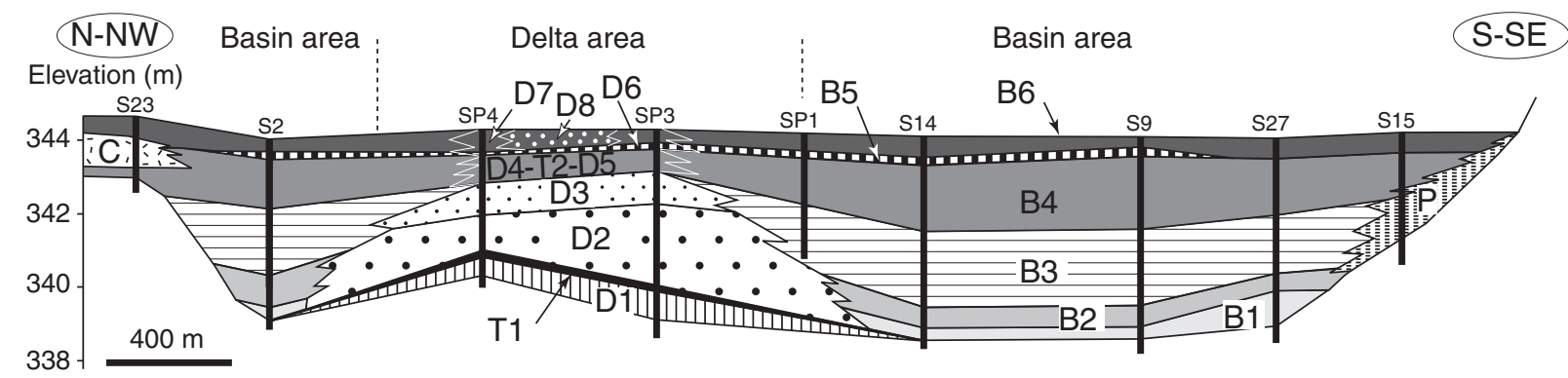

\section{B - Cross-section II}

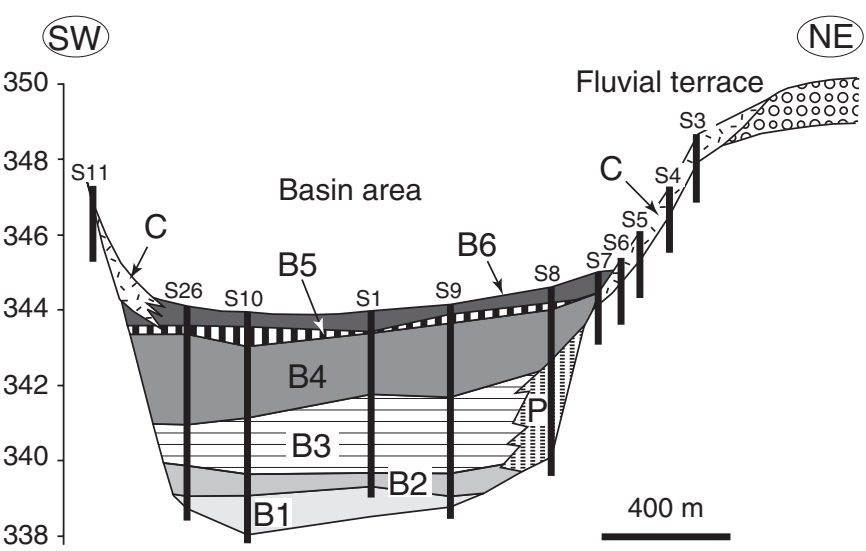

C - Late Glacial up to 13.7 kyrs cal BP

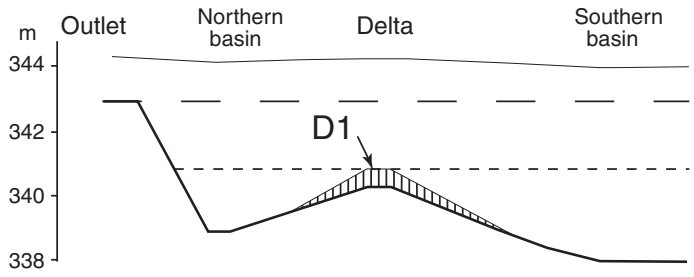

D - At ca. 13.7 kyrs cal BP

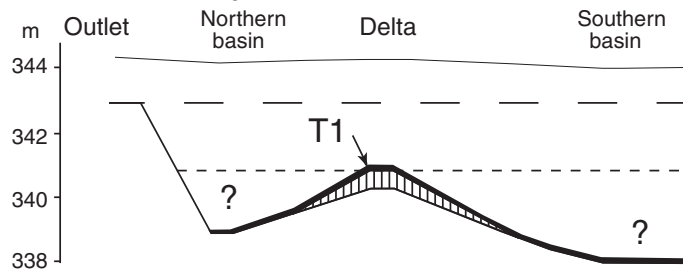

E - Ca. 13.7 kyrs cal BP - ca. 11.5 kyrs cal BP

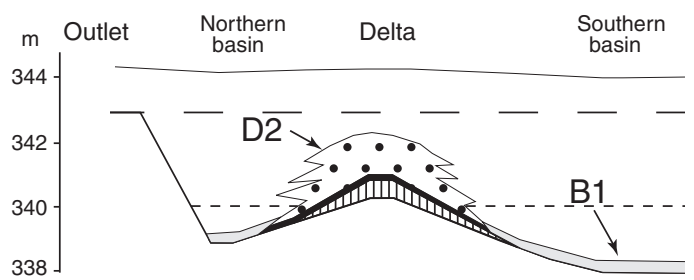

F - Ca. 11.5 kyrs cal BP - ca. 9.8 kyrs cal BP

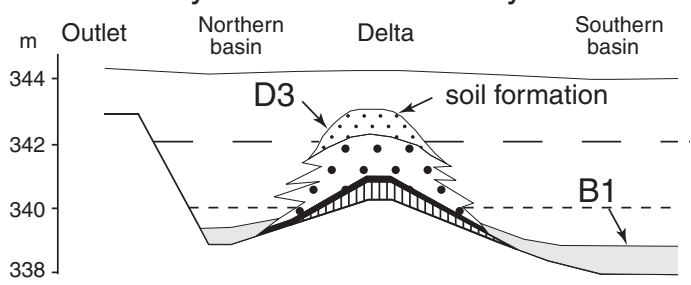

G - Ca. 9.8 kyrs cal BP - ca 7.5 kyrs cal BP

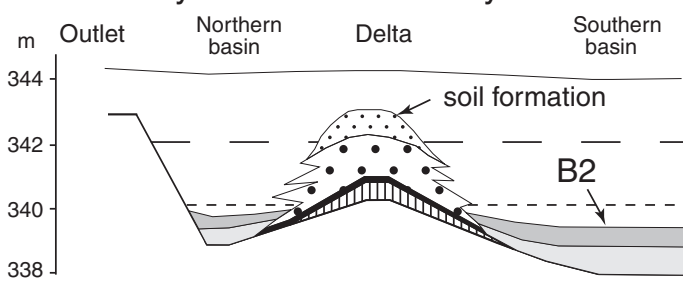

H - Ca 7.5 kyrs cal BP - ca 5.3 kyrs cal BP

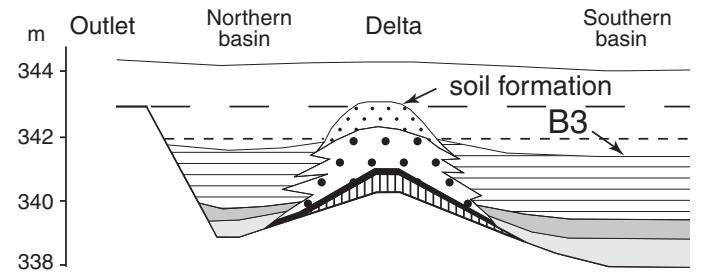

I - Ca 5.3 kyrs cal BP - ca 2.3 kyrs cal BP

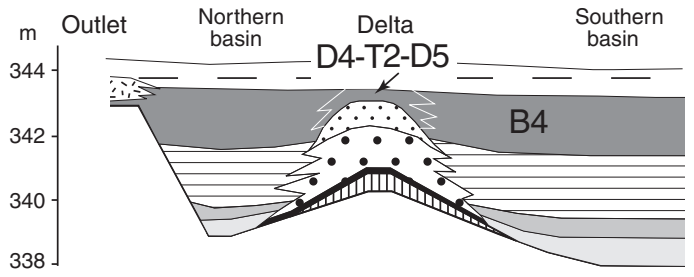

J - Ca 1.8 kyr cal BP - ca 0.3 kyr cal BP

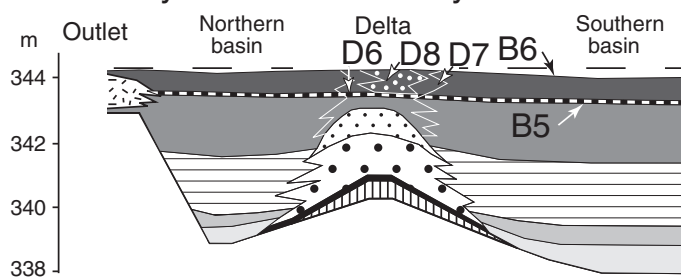

probable usual water level

Figure 2. Cross-sections through sediments (A, B) and pattern of Sarliève palaeolake evolution since the Lateglacial up to the seventeenth century (C to J) (from Fourmont et al., 2009). Location of I and II cross-sections, see Figures 1 and 4B. S2, S9, core drilling; SP3, SP4, pit section; D1 to D7, delta deposits (T1 and T2, tephras); B1 to B6, distal basin deposits; P, proximal basin deposits; C, colluvium 
sediments, generally carbonate-rich, showing from base to top: B1 unit, quartz-rich compact yellowish to greenish clayey-silts (CS), characterized by the presence of zeolites; B2, grey to blue clayey-silts mainly composed of authigenic dolomite; B3, alternation of dark calcitic CS (cm-thick layers) with bundles of dolomitic and aragonitic laminae; B4, homogeneous greenish calcitic CS; B5, charcoal-rich black calcitic CS; B6, greenish-grey to brown calcitic CS. The lower part of proximal basin deposits contains a dark sandy layer incorporating reworked pyroclastic particles (similar to $\mathrm{T} 1$ and $\mathrm{D} 2$ ).

The following palaeohydrological and sedimentological scheme of the lake's evolution (Fourmont et al., 2009) has been drawn up from distribution and comparison of sedimentary facies, ${ }^{14} \mathrm{C}$ datings, tephra ages and detailed mineralogical and geochemical analysis.

During the Lateglacial up to $c .13700 \mathrm{yr}$ cal. BP (mainly Bölling), D1 unit sediments, containing c. 30\% travertine-like precipitated material, were deposited in the delta area; no evidence of coeval sediments was found in basins. Water level was low, with a maximum depth of c. $5 \mathrm{~m}$ (Figure 2C). At c. 13700 yr cal. BP, at around the beginning of the Alleröd, direct CF1 tephra (Vernet and Raynal, 2000) was deposited (T1 unit, Figure 2D). While it probably covered the whole catchment area, CF1 tephra has only been observed in delta sediments where it was buried under the $\mathrm{D} 2$ unit deposited in a fan-type delta during the period $13700 \mathrm{yr}$ cal. BP-11 $500 \mathrm{yr}$ cal. BP (Alleröd and Younger Dryas) (Figure 2E). The D2 unit, exclusively detrital in origin, includes layers of tephra reworked from catchment slopes, suggesting a rise in water level during flood event(s) to more than c. $342 \mathrm{~m}$, which probably led to a short-lived opening of the lacustrine depression. However, during the same period, from $13700 \mathrm{yr}$ cal. BP up to c. $9800 \mathrm{yr}$ cal. BP, authigenic zeolites and quartz formed in the distal basin B1 unit, partly because of alteration of CF1 tephra, and indicating endorheic conditions with a generally low water level and reduced detrital input ( $c$. $60 \%$ of B 1 sediments) (Figure 3 ).

After c. $11500 \mathrm{yr}$ cal. BP (early Holocene), colluvium (D3 unit) was deposited on the emerged delta area (Figure 2F). Soil formed at the top of D3, probably during the early and middle Holocene until the end of the Atlantic period (Figure 2G, H). During this period (9800 yr cal. BP until $7500 \mathrm{yr}$ cal. BP) authigenic dolomite-rich sediments (B2 unit) formed in the basins, indicating perennial endorheic conditions. The biochemical dolomite content increased in the B2 sediments from $30 \%$ (bottom) to $60 \%$ (top), indicating maximum restriction at around $8000 \mathrm{yr}$ cal. BP (Figure 3). The water level did not reach the top of D3, and the water was probably quite shallow (less than 1-2 $\mathrm{m}$ deep).

During the middle Holocene, from c. $7500 \mathrm{yr}$ cal. BP until $c$. $5300 \mathrm{yr}$ cal. BP (Atlantic period), when the delta area was never flooded (Figure 2H), unit B3 was deposited in the basins. Interbedding of laminated biochemical sediments (BL facies) with detrital sediments (homogeneous clayey-silts: HCS facies) indicates variations in palaeohydrology and related depositional conditions. Bréhéret et al. (2008) identify three phases of BL-HCS facies sedimentation: (1) dolomite authigenesis in BL under restricted conditions similar to $\mathrm{B} 2$; (2) aragonite genesis in $\mathrm{BL}$, indicative of $\mathrm{Ca}^{2+}$-rich freshwater inputs when facies are composed of $20 \%$ to $60 \%$ biochemical phases (Figure 3) and deposited while lake waters were salty; and (3) HCS facies, where biochemical phases constituted less than $10 \%$, indicating increased

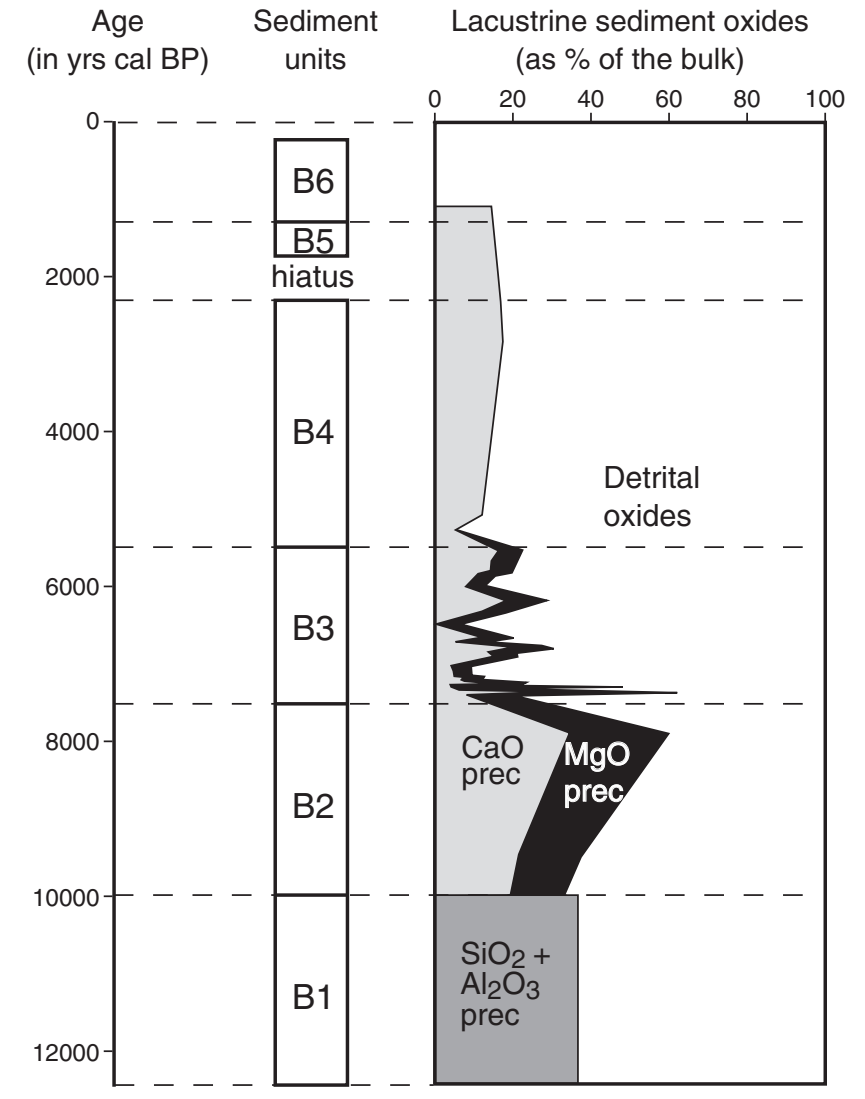

Figure 3. Evolution of contents in detrital and precipitated fractions in Sarliève palaeolake basin sediments (core S17). CaOprec, MgOprec and $\mathrm{SiO}_{2}+\mathrm{Al}_{2} \mathrm{O}_{3}$ prec, precipitated $\mathrm{CaO}, \mathrm{MgO}$ and $\mathrm{SiO}_{2}+\mathrm{Al}_{2} \mathrm{O}_{3}$ in percents of lacustrine bulk sediments (from Fourmont et al., 2009). $\mathrm{SiO}_{2}+\mathrm{Al}_{2} \mathrm{O}_{3}$ were precipitated from CF1 tephra weathering

detrital input during periods with low water level and salty water, ending with the input of fresh water. This trend could be related to repeated time-limited fluctuations of the water level which was generally below the top of D3 palaeosoil, i.e. c. 342/343 m. The duration of one BL + HCS deposition sequence has been evaluated at $150 \mathrm{yr}$ on average in B3 and $470 \mathrm{yr}$ at the maximum between $7100 \pm 150 \mathrm{yr}$ cal. BP and $7260 \pm 160 \mathrm{yr}$ cal. BP. However, the gradual thickening of detrital HCS facies towards the top of B3 indicates the increasing input of fresh water and the possible temporary opening of the system.

The sediment geometry shows that the water level was high during the late Holocene from $5.3 \mathrm{ka}$ cal. BP: B4 to B6 units accumulated when the lake extended, covering the delta area and border deposits (Figure 2I, J). Water-level altitude must have been at least $343 \mathrm{~m}$ at the beginning of the sub-Boreal, and 344/345 $\mathrm{m}$ in the seventeenth century. Apart from the D4 sandy transgressive facies and local D8 sandy-gravelly deltaic facies, the upper sediments of the whole delta (D5 to D7 units) and basin (B4 to B6 units) have a homogeneous composition. They contain more than $80 \%$ detrital materials, and biochemical calcite is always $<20 \%$ (Fourmont et al., 2009; Figure 3). The waters were probably continuously fresh, implying a perennial body of water in the lake, total opening of the depression and continuous water supply from the catchment. However, archaeological data (Gallo-Roman settlements, cemetery and drainage networks in the palaeolake basins) show that the lake dried up between the third century $\mathrm{BC}$ and second century $\mathrm{AD}$ 
because of human activities (Trément et al., 2007b). Moreover, 'catastrophic' flood(s) occurred between the fourth and seventeenth centuries $\mathrm{AD}$, causing sandy-gravelly fan delta deposition (D8 unit), and resulting in the water level rising above $346 / 347 \mathrm{~m}$. Finally, the lake was drained during the seventeenth century (Fournier, 1996), and since then the water has run in artificial channels.

\section{Methods}

\section{Evaluation of catchment physiographical characteristics and calculation of sediment yield rates}

Some parameters of relief and lithology were analysed using GIS. Slope gradient and true surface area of the catchment were calculated from DEM using Arcview 8.2 software and digitizing elevation contour lines of Institut Géographique National (IGN) 2531E and 2532E 1/25 000 maps. Surface areas of main types of rocks were assessed by digitizing XXV-31 'Clermont-Ferrand' 1/50 000 geological map (Jeambrun et al., 1973).

Sediment yielded by catchment was calculated in $t / \mathrm{km}^{2}$ per $\mathrm{yr}$ from stored lacustrine sediment mass. Volumes of main sedimentary units (delta sediments: units D1 to D8, and T1 tephra; basin sediments: units B1 to B6) were calculated from their thickness and extent using different methods. Facies and thickness of sediments were observed directly (1) from 13 pit sections of $8 \mathrm{~m} \times 8 \mathrm{~m}$, carried out up to a depth of $3.3 \mathrm{~m}$ by the Institut National de Recherches Archéologiques Préventives (INRAP) for an archaeological survey of the construction site of the 'Grande Halle d'Auvergne', located near by the delta area, and (2) from 31 core drillings retrieved with a percussion sampler (Eijkelkamp) by the geological laboratory of Tours (UMR CNRS 6113 ISTO) in northern and southern distal basins (Figure 4B). Sediment thickness and extent were determined using 56 geotechnical tests (static penetrometry using $100 \mathrm{KN}$ penetrometer) carried out by FondasolAuvergne: penetrometric data mainly identified hard substratum (resistance to penetration $R>6 \mathrm{Mpa}$ ), and with regard to lacustrine sediments, clayey silty (B1 to B6, D1, D4 to D7 units: $R<2$ $\mathrm{MPa}$ ), sandy-silty (T1, D2 and D3 units: $2<R<6 \mathrm{MPa}$ ) and gravelly-sandy (D8 unit: $R>6 \mathrm{Mpa}$ ) bodies, according to data of Antoine and Fabre (1980).

In the northern and southern basins about $50 \mathrm{~km}$ of electromagnetic profiling was performed using an average recording distance of $7 \mathrm{~m}$ along the profiles, a lateral spacing of $20 \mathrm{~m}$ to $100 \mathrm{~m}$, an EM 31 instrument, and the slingram method (Mc Neil, 1980) (Figure 4C). Electrical conductivity of surficial deposits up to about $6 \mathrm{~m}$ depth was calibrated with lithological facies observed from core drillings. Sixteen electrical soundings were also performed. Based on the geophysical survey, the total thickness of lacustrine sediments in basins and the thickness and extent of sediment units mainly composed of precipitated (B1 to B3) and detrital material (B4 to B6) were determined (Hinschberger et al., 2006). Spatial analysis of these data (elevation of bottom and top, and 3D extent of units) were performed using SIG (Arcview 8.2; Fourmont, 2005). Interpolation by kriging was used to delineate the shape of lacustrine sediment units, based on which sediment volumes were calculated. It was not possible to distinguish the limit between T1 (tephra) and D2 (tephra-rich delta sediments) units, as their grain sizes are similar. Likewise, clayey-silty D6-B5 (charcoal-rich black calcitic CS) and D7-B6 (greenish-grey to brown calcitic CS) units could not be distinguished (Figure 2).

The apparent volumetric mass (dry weight divided by the wet volume, in $\mathrm{t} / \mathrm{m}^{3}$ ) of the basin-unit sediments was calculated by weighing sediments after given volumes of sediments were dried at $40^{\circ} \mathrm{C}$ for $48 \mathrm{~h}$. We decided that the apparent volumetric mass of lower sandy delta units, which could not be measured, was $1.5 \mathrm{t} / \mathrm{m}^{3}$, based on data of Macaire et al. (2006). The sediment mass for each unit was calculated by multiplying the unit's volume with the experimentally derived volumetric mass. From these data we calculated the mass of material (detrital and precipitated) forming each lithological unit, using the data of Fourmont et al. (2009). For B3 unit, composed of alternating precipitated material-rich laminae (BL) and detrital material-rich layers (HCS), the whole sediment mass was calculated from the volumetric mass of BL and HCS facies weighted by their relative thickness in the unit. The evolution of the mass of precipitated material compared to detrital material from bottom to top in B3 was deduced from evolution of the thickness of BL compared with HCS facies.

Age and period of formation of each lithological unit were calculated based on the chronological model of Fourmont et al. (2009), that is based on 18 calibrated ${ }^{14} \mathrm{C}$ ages of seeds, charcoal and bulk sediment organic matter, performed by the CDR (Centre de Datation par le Radiocarbone, Lyon 1 University), completed with information from pollen zones, tephrochronology and archaeological data. The base of D1 was arbitrarily chosen as the beginning of the Bölling (15000 yr cal. BP). Deposition of D3 colluvium was attributed to the Preboreal (duration: $1100 \mathrm{yr}$ ), and palaeosoil formation on this colluvium to the Boreal and Atlantic (duration: about $5100 \mathrm{yr}$ ).

Sediment source area for calculation of the sediment yield was determined for each unit as the difference between the total catchment area and the unit surface area in the lacustrine area. Sediment yield rates were estimated in $\mathrm{t} / \mathrm{km}^{2}$ per yr by dividing the each unit's sediment mass by the surface of sediment source and the time period of formation of the unit. Total sediment yield (TSY) was calculated, as well as solid (SSY) and dissolved (DSY) sediment yields. It was possible to distinguish between detrital and precipitated material in sediments thanks to geochemical, XRD, SEM and EDS analyses. Mineral study suggests that, except in B1, silicates (quartz, feldspars, zeolites and clay minerals) are mainly detrital, and carbonates (calcite, dolomite and aragonite) are both detrital and in situ precipitated (biochemical). For each unit, the mass of precipitated $\mathrm{MgO}$ and $\mathrm{CaO}$ carbonates have been quantified (details in Fourmont et al., 2009), (1) from $\mathrm{MgO}$ and precipitated dolomite contents in sediments determined from geochemical analyse and SEM observation, respectively, (2) by comparing $\mathrm{CaO}$ contents in sediment and catchment soils for each period. From this investigation, the uncertainty in determination of SSY and DSY values can be evaluated to $\pm 20 \%$.

\section{Pollen study}

Pollen analysis (pollens data used for the chronological model of Fourmont et al., 2009) was carried out on samples collected by increments of $3 \mathrm{~cm}$ in P core performed with Russian core sampler in the northern basin (Figure 4B). After eliminating carbonate and siliceous components of sediments, pollen grains were concentrated with 'Thoulet' solution $(d=2)$ (Goeury and de Beaulieu, 1979). 


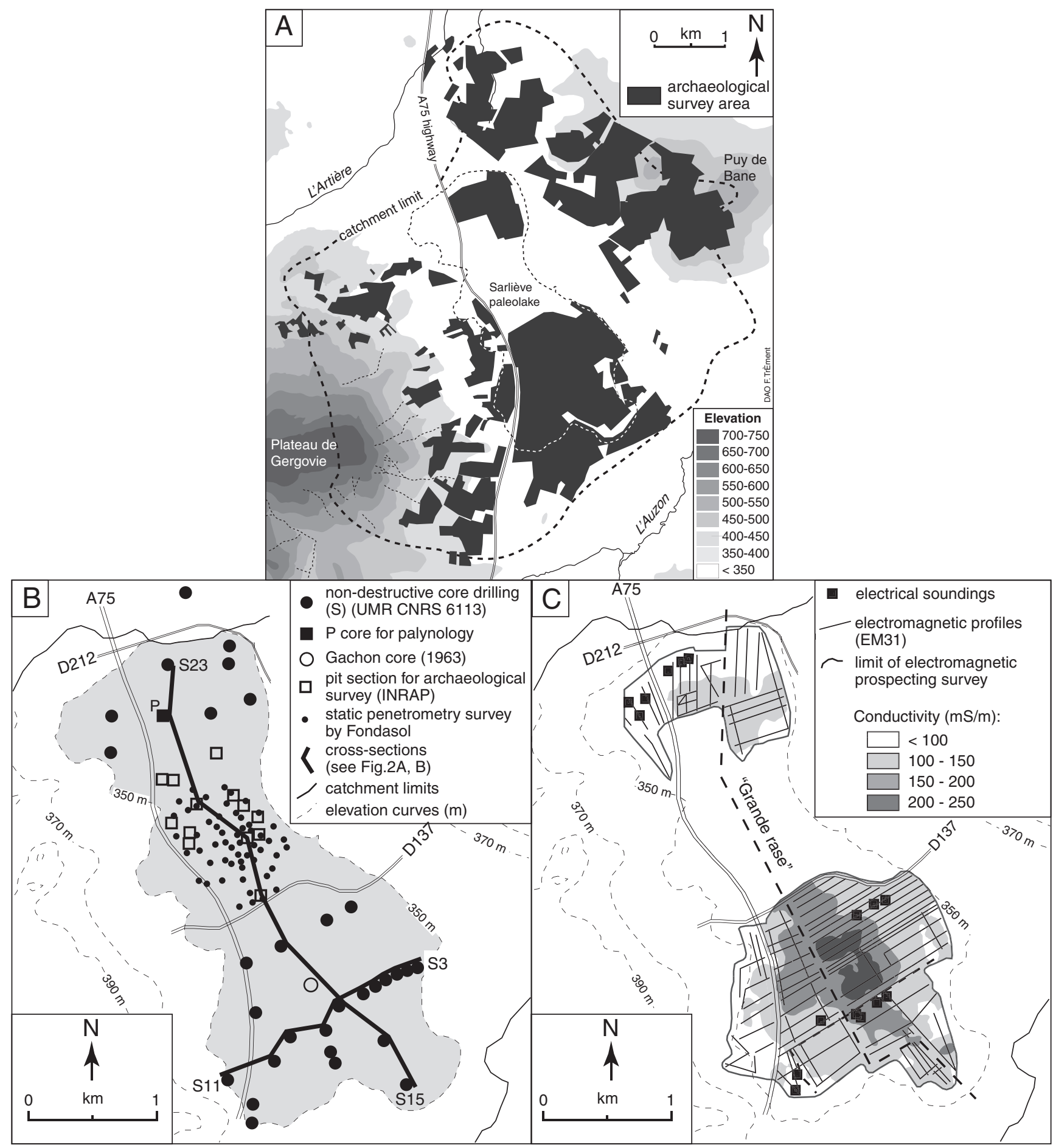

Figure 4. Location of surveys. (A) Archaeological survey area in whole catchment; (B) location of core drillings, pit section for archaeological survey and static penetrometry survey in palaeolake area; (C) geophysical survey in palaeolake area

A minimum of 300 pollen grains were identified and counted in each sample. To make it easier to interpret pollen, taxa were separated into two classes: those characteristic of wetland (area in direct contact with the Sarlieve palaeolake), and those characteristic of the catchment. The abundance of pollen grains was calculated as a percentage of each class and analysed separately. Chenopodiaceae, which are not strictly related to either class, and Tertiary taxa were calculated as a percentage of the whole pollen grains. Data on non-pollinic microfossils studied on P core were taken from Argant and Lopez Saez (2004).

\section{Historical study and archaeological survey}

The history of human settlement was investigated through exhaustive bibliographical study of the nine districts in the catchment. Five systematic archaeological field surveys, with intervals of $10 \mathrm{~m}$ and sampling of the whole archaeological material on each site, were performed between 2001 and 2003, in accessible areas with no buildings, representing $40 \%$ of the whole catchment area (Trément et al., 2007b; Figure 4A). Four spatial archaeological units were identified for different periods: (1) site, which has a 
concentration of artefacts providing evidence of human activity at a precise place, (2) probable site, which has insufficient evidence, (3) isolated artefact, for a notable artefact, and (4) off-site pottery, representing a 'background noise' of scattered and often subrounded abundant artfacts resulting from farming-related soil enrichment. Statistical analyses of the sites interpreted as settlements were carried out for each period: number, distribution by elevation and total surface area. In addition, the 13 pit sections carried out by INRAP before the construction of the Grande Halle d'Auvergne (Vernet et al., 2005) were studied; they cover a surface area of 90 ha in the palaeolake delta zone at its eastern and western borders where there is a large site $\left(7500 \mathrm{~m}^{2}\right)$ (Figure 4B).

\section{Results}

\section{Catchment physiography}

Catchment slope gradients vary from about $0^{\circ}$ in the Sarliève depression to $49^{\circ}$ on the eastern side of the 'Plateau de Gergovie' (Figure $5 \mathrm{~A}$ ). Slope gradients are lower than $2^{\circ}$ on $40 \%$ of the catchment area and above $8^{\circ}$ on about $20 \%$. Percentages of main rockoutcrop surfaces are shown in Figure 5B: carbonated rocks cover about $75 \%$ of the catchment in low to medium slope gradient areas.

\section{Sediment yield (SY)}

Rates of total (TSY), solid (SSY) and dissolved (DSY) sediment yields, and data for their calculation are shown in Figure 6A,B,C and in Tables 1 and 2, respectively. During the Lateglacial and Holocene, SSY and DSY varied from 6 to $203 \mathrm{t} / \mathrm{km}^{2}$ per yr and from 4 to 44 $\mathrm{t} / \mathrm{km}^{2}$ per yr, respectively. Nine sediment yield phases (SYp1 to SYp9) were identified. During the Bölling and at the beginning of the Alleröd (SYp1), SSY (19 t/km ${ }^{2}$ per yr) and DSY ( $8 \mathrm{t} / \mathrm{km}^{2}$ per yr) rates were low. During the second part of the Alleröd and the younger Dryas (SYp2), SSY (65 t/ $\mathrm{km}^{2}$ per yr) and DSY (31 t/km² per yr) increased significantly. During the Preboreal and at the beginning of the Bölling (SYp3), SSY decreased slightly (52 to $46 \mathrm{t} / \mathrm{km}^{2}$ per yr), while DSY did not vary. The lowest SY rates appeared during the Bölling and at the beginning of the Atlantic (SYp4): SSY decreased from 11 to $6 \mathrm{t} / \mathrm{km}^{2}$ per yr, while DSY increased from 4 to $9 \mathrm{t} / \mathrm{km}^{2}$ per yr. During the Atlantic and at the beginning of the sub-Boreal (SYp5), there was considerable variation between SSY and DSY rates (24 to $55 \mathrm{t} / \mathrm{km}^{2}$ per yr and 37 to $6 \mathrm{t} / \mathrm{km}^{2}$ per yr, respectively): SSY and DSY increased alternately during this period, with a general pattern of SSY increase and DSY decrease. During the sub-Boreal and at the beginning of the sub-Atlantic (SYp6), SSY increased considerably (161 t/km² per yr), and DSY rose to $40 \mathrm{t} / \mathrm{km}^{2}$ per yr. The SY rate for the period between 2300 and $1800 \mathrm{yr}$ cal. BP (SYp7) could not be calculated as there were no stored sediments due to lake-water drainage at this time. SY rates were highest during the sub-Atlantic from 1800 to $300 \mathrm{yr}$ cal. BP (SYp8), up to $203 \mathrm{t} / \mathrm{km}^{2}$ per yr between 1600 and $300 \mathrm{yr}$ cal. BP (SYp8b) for SSY, and $44 \mathrm{t} / \mathrm{km}^{2}$ per yr for DSY. SY could not be evaluated for the period after $300 \mathrm{yr}$ cal. BP because of the lake drying up.

SSY was generally greater than DSY, except at the end of SYp4 and the beginning of SYp5. The DSY/SSY ratio (Figure 6D) remained close to 0.5 with a slight increase ( 0.42 to 0.67$)$ between SYp1 and SYp3. This ratio increased sharply to 1.54 during SYp4 (beginning of the Atlantic), then decreased with variations to 0.11 at the end of SYp5. After that, the DSY/SSY ratio did not vary significantly, remaining around 0.25 during SYp6 and SYp8.
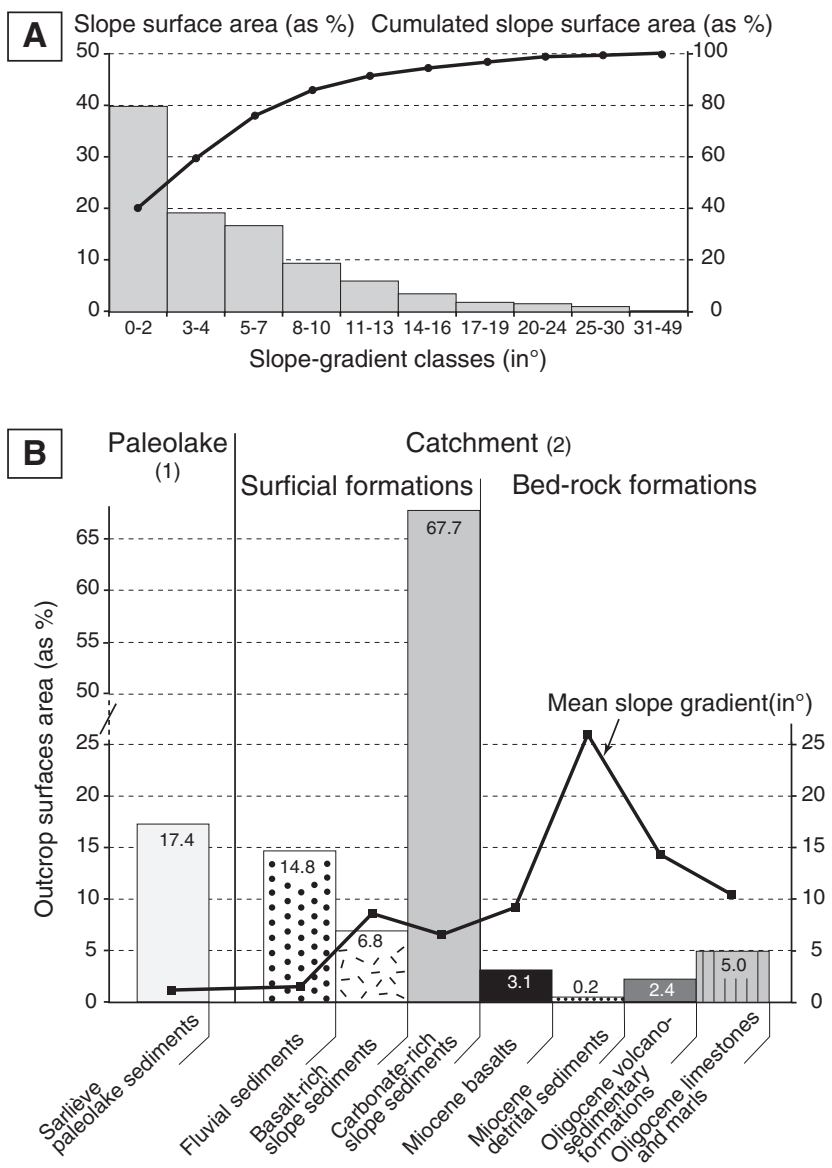

Figure 5. Physiographical data of Sarliève catchment. (A) Catchment slope gradients. (B) Lithology and mean slope gradients by lithological area. (1) lithology as per cent of whole catchment area $\left(29 \mathrm{~km}^{2}\right)$; (2) lithology as $\%$ of sediment-yielding catchment area $\left(24 \mathrm{~km}^{2}\right)$

\section{Palynology}

Palynological data obtained from study of the P core concern B3 to B6 lithological units (Atlantic to late sub-Atlantic). The taxa, described in detail in Argant and Lopez Saez (2004), are presented in this paper in two environments: catchment and wetland (Figure 7). This made it possible to investigate the relationship between SY rates and plant cover during anthropogenic impact periods (Ep5 to Ep8). These elements further Gachon's data (1963) on vegetation in the Sarliève area for the whole Holocene and are in line with Prat's data (2006) for the sub-Boreal and sub-Atlantic.

Catchment plant cover (Figure 7A) was dominated by forest (50-85\% of arboreal pollen) up to the end of the sub-Boreal. During the Atlantic, Quercus and Corylus dominated (pollinic zones a, b and c) with Ulmus and Tilia; during periods of reduced arboreal pollen grains, Corylus decreased more than Quercus. After that, Fagus and Abies appeared (zone d) and developed during the sub-Boreal (zones e, f, g and h), mainly to the detriment of Corylus. At the beginning of the sub-Atlantic there was a sharp decline of forest taxa (always lower than 40\%: zones i and j), dominated by Pinus. Poaceae were always present ( 5 to $20 \%$ of pollen grains in the catchment), but dominated (up to about $50 \%$ ) only in zone i, at the beginning of the sub-Atlantic. Ruderals (Plantago, Artemisia, Centaurea, Cichorioideae, Asteraceae, Polygonum, Lamiaceae, Apiaceae), except Chenopodiaceae, were found from the beginning of the Atlantic (zone a); they were temporarily more abundant in zone $\mathrm{c}$ with a marked increase at the sub-Atlantic (up to $45 \%$ in 


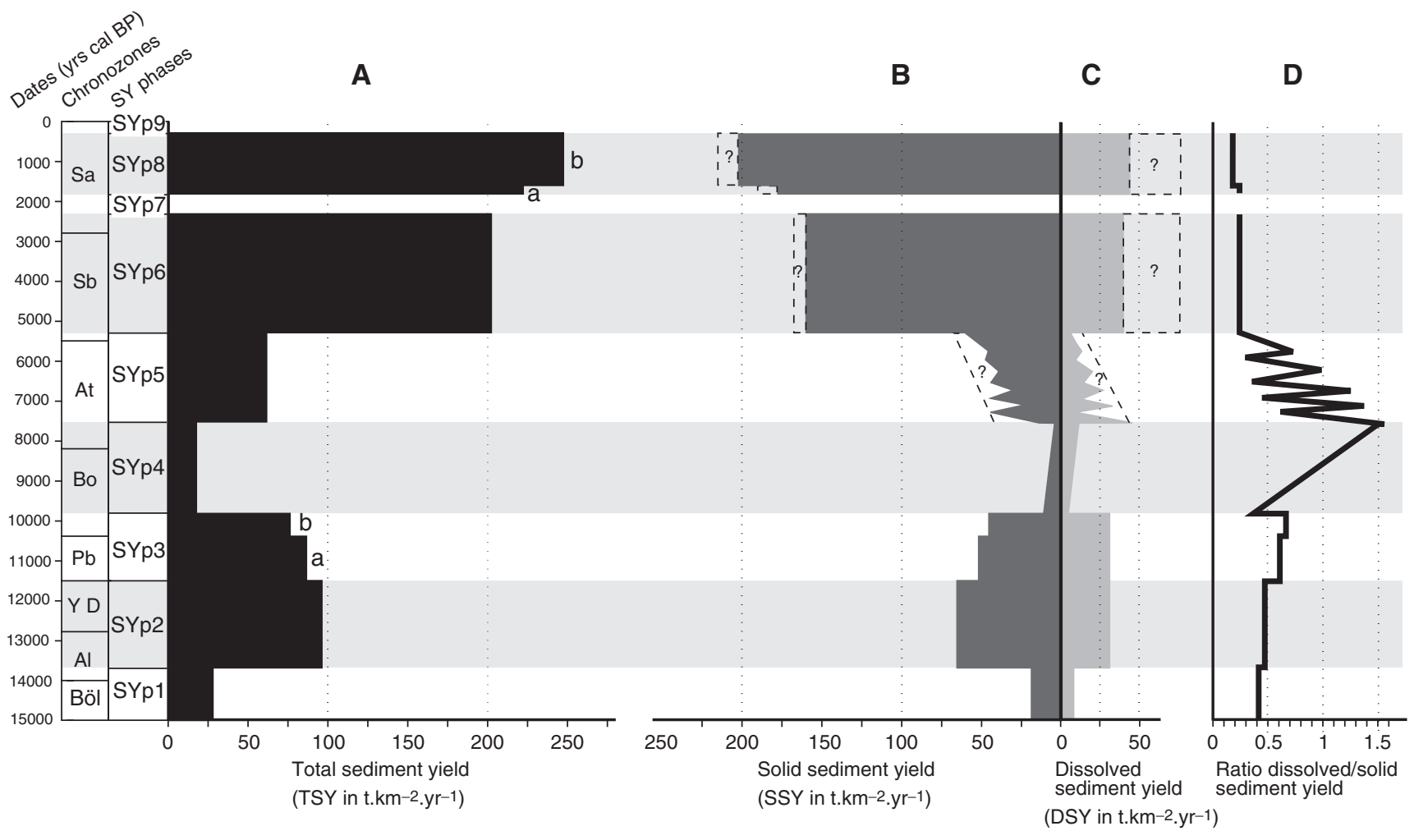

Figure 6. Rates of sediment yield (SY) during the Lateglacial and Holocene in Sarliève catchment. Chronozones from Boivin et al. (2004). (A) Total sediment yield, (B) solid sediment yield, (C) dissolved sediment yield, and (D) ratio of dissolved/solid sediment yield

zone j). Cereals, not observed in pollinic zone a, appeared as traces in zone $\mathrm{b}$ and remained present, with pollen-grain contents temporarily higher during the sub-Boreal in zones e and $f$ and up to about $20 \%$ of catchment taxa in zone $\mathrm{j}$.

Wetland vegetation (palaeolake edge) was also characterized by the predominance of arboreal taxa (mainly Alnus, with Fraxinus and Salix) during the Atlantic and sub-Boreal (Figure 7D), with greater and more frequent variations in the abundance of arboreal taxa during the Atlantic (30-80\% arboreal pollen grains dominated by Fraxinus: zones a to d) than during the sub-Boreal (55 to 85\%, dominated by Alnus: zones e, f and g). Arboreal taxa decreased sharply at the end of this period ( $5 \%$, bottom of zone i). During the sub-Atlantic, arboreal taxa first increased (up to 50\%, zone i), then decreased sharply (5-20\%, zone j). Areas without forest were mainly covered by Cyperaceae which were particularly abundant at the end of the sub-Boreal (zone h) and at the beginning of the sub-Atlantic (zone i). Aquatics sometimes appear.

Chenopodiaceae (Figure 7C) were always present, but more abundant at the beginning of the Atlantic (zone a: up to $15 \%$ of total pollen grains), temporarily during the sub-Boreal (zones $f$ and $\mathrm{h}$ ) and sub-Atlantic (zones $\mathrm{i}$ and $\mathrm{j}$ ). Tertiary taxa (mainly Gymnosperma) were always present (Figure 7B), often forming $10 \%$ of total pollen grains, particularly during periods of catchment arboreal taxa decrease, but they were as high as $90 \%$ in pollinic zone e at the beginning of the sub-Boreal.

\section{Archaeology}

Surface archaeological survey results have been described in detail by Trément et al. (2007b). They are summarized in Figures 8 and 9. Evidence for the Neolithic is found in 21 sites (S), 7 probable sites (PS) and 12 isolated artefacts (IA) observed on the land surface within the Sarliève catchment (Figure 8A). Evidence for the early Neolithic (Recent Cardial) has been found, although poor, while evidence for the late/final Neolithic, difficult to identify, is sparse and mainly located in high elevation areas. Evidence of the middle Chassean Neolithic dominates (17S, 3PS and 5IA), mainly located on slopes of the Plateau de Gergovie on the west and slopes of the Puy d'Anzelle and Puy de Bane on the east of the catchment.

There is particularly abundant evidence of the ancient Bronze Age (14S, 6PS and 1IA), especially on the Plateau de Gergovie and Puy d'Anzelle slopes, and always at an elevation above $360 \mathrm{~m}$ (Figure 8B). There is some evidence of the middle Bronze Age (5S, 1PS and 1IA) at the same location as evidence of the ancient Bronze Age and above $370 \mathrm{~m}$. There is abundant evidence of the final Bronze Age (10S, 3PS, 1IA) and 1 funerary site (FS); they are mainly located on western and eastern catchment slopes, and the funerary site is the first evidence of human settlement in the Sarliève depression at an elevation of $346 \mathrm{~m}$.

Evidence of the first Iron Age is very abundant (17S, 7PS), mainly on slopes, from the eighth century BC. This evidence is not found on the plateau, but in areas close to the palaeolake. There is only a little evidence of the ancient and middle La Tène (fifth-third centuries $\mathrm{BC}$ ) (7S, 4PS, 1IA and 3FS), mainly found at low elevation (387 $\mathrm{m}$ on average). Human pressure increased sharply during the final La Tène (second-first centuries BC) (Figures 8C and 9): 24S, $15 \mathrm{PS}$ and $2 \mathrm{FS}$, especially at lower elevations (53\% of evidence is found below $350 \mathrm{~m}$ ), at the edge of the eastern alluvial terrace close to the palaeolake and in the northern outlet area, although the whole catchment was settled by humans at that time. Off-site pottery resulting from farming-related soil enrichment is closely associated with sites. Land parcels with boundary markings and drainage ditches, dating from the second half of the first century BC, have been discovered at the bottom of the lacustrine depression. 


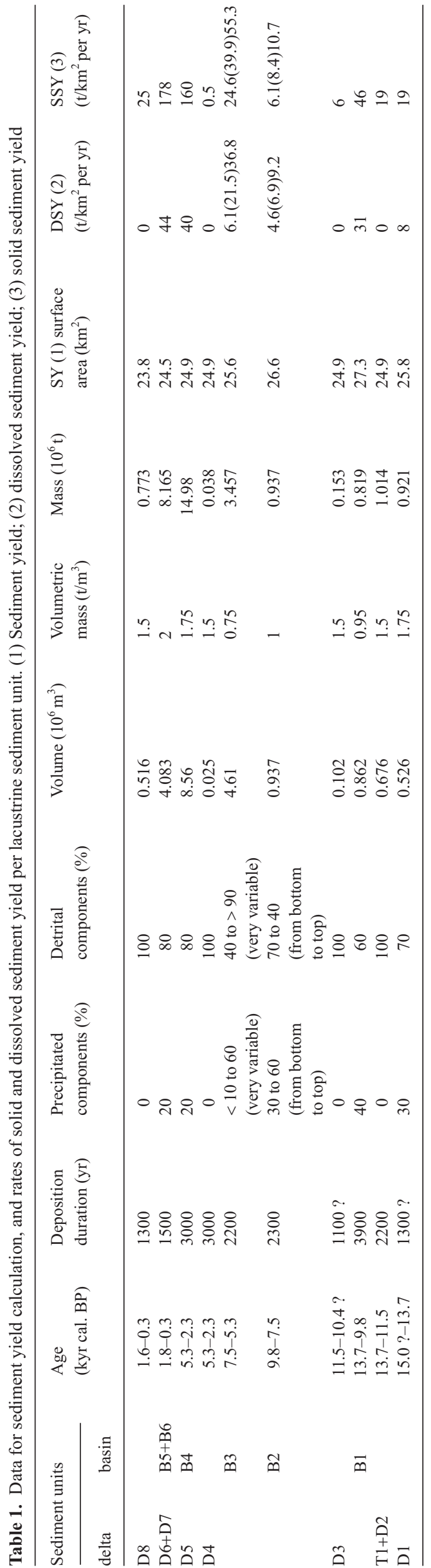

The early Roman Empire (first-second centuries $\mathrm{AD}$ ) is characterized by a sharp increase in signs of settlement (57S, 31PS and 11FS) throughout the catchment (hilltops, slopes, edge and bottom of lacustrine depression); mean elevation of sites is low: $390 \mathrm{~m}$. The off-site pottery area is widespread. Sites were either vast agricultural domains (or villae) (Trément, 2007b), or buildings belonging to the villae, or small farms. During the late Roman Empire (third-fifth centuries AD) (Figures 8D and 9), only 17 of the former 57 sites remained, mainly located at the edge of the palaeolake (mean elevation: $383 \mathrm{~m}$ ), in the same place as the main early Roman Empire buildings (villae).

During the early Middle Ages, settlements were still few (5S, 4PS, 2IA and 2FS) and always located at very low elevations (mean: $351 \mathrm{~m}$ ): slopes and plateaus seem to have been deserted. The off-site pottery area was also less extensive than during the early Roman Empire. Four of the five sites were occupied continuously from the final $\mathrm{La}$ Tène and became vast seigniorial domains during the Middle Ages.

Archaeological excavations carried out before the construction of the 'Grande Halle d'Auvergne' (Vernet et al., 2005; Trément et al., 2007b) discovered a funerary site with a tumulus dating from the final Bronze Age and extensive settlement between the third century $\mathrm{BC}$ and second century $\mathrm{AD}$ at the northeastern edge of the palaeolake. During the La Tène period, settlement, comprising workshops, wells and burial places, was highly structured with enclosures and drainage networks. There is evidence of human activity (wells, parcels with boundary marking) on the northern lacustrine depression bottom at the time of the Roman conquest (Gergovia battle: $52 \mathrm{yr} \mathrm{BC}$ ) and during the early Roman Empire (buildings, collection of spring water, funerary sites) up to the third century AD. Evidence of fisheries dating back to the Middle Ages and Modern Times have also been found.

\section{Discussion}

\section{Significance of rates and phases of sediment yield}

Calculated TSY, SSY and DSY rates are averages for the whole sediment yield surface area (27.3 to $23.8 \mathrm{~km}^{2}$ according to period, Table 1). In the catchment, spatial distribution of SY varied according to earth surface conditions, particularly slope gradient $\left(0-49^{\circ}\right)$ and lithology (dominance of basalt or limestone and marl) (Figure 5). Moreover, SY rates are averages of SY phases whose duration depends on datation possibility and during which SY could vary due to catastrophic climatic events when retention rates of particles in the lake might have been low (Brune, 1953). Nine sediment yield phases (SYp1 to SYp9) were identified covering the main chronozones of the Lateglacial and Holocene (Figure 6).

Calculated SSY rates (Figure 6B) are minimum rates which can be considered close to true rates because many factors are favourable to high palaeolake-trap efficiency (Heineman, 1984; Einsele and Hinderer, 1998): high lake/catchment area ratio (average of 0.16), lake often closed or shallow when open, lake water rich in $\mathrm{Ca}^{2+}$ and $\mathrm{Mg}^{2+}$ favouring clay flocculation, and inflow mainly due to runoff with no river. During the Lateglacial and early and middle Holocene (SYp1 to 5), endorheism is shown in basin sediments by abundance of minerals (analcite, dolomite, aragonite) resulting from chemical or biochemical precipitation in salty water. Particle retention in the palaeolake was favoured by 
Table 2. Rates of solid and dissolved sediment yield per sediment yield (SY) phase. (1) Dissolved sediment yield; (2) solid sediment yield; (3) total sediment yield

\begin{tabular}{|c|c|c|c|c|c|c|}
\hline SY phases & Ages (kyr cal. BP) & Sediment units & DSY (1) $\left(t / \mathrm{km}^{2}\right.$ per yr) & SSY (2) $\left(\mathrm{t} / \mathrm{km}^{2}\right.$ per yr) & TSY (3) $\left(\mathrm{t} / \mathrm{km}^{2}\right.$ per yr) & DSY/SSY ratio \\
\hline SYp9 & $0-0.3$ & no sediments & $?$ & $?$ & $?$ & ? \\
\hline \multicolumn{7}{|l|}{ SYp8 } \\
\hline $\mathrm{b}$ & $0.3-1.6$ & $\mathrm{D} 6+\mathrm{D} 7+\mathrm{D} 8+\mathrm{B} 5+\mathrm{B} 6$ & 44 & 203 & 247 & 0.22 \\
\hline $\mathrm{a}$ & $1.6-1.8$ & $\mathrm{D} 6+\mathrm{D} 7+\mathrm{B} 5+\mathrm{B} 6$ & 44 & 178 & 222 & 0.25 \\
\hline SYp7 & $1.8-2.3$ & no sediments & $?$ & $?$ & $?$ & $?$ \\
\hline SYp6 & $2.3-5.3$ & D4+D5+B4 & 40 & 161 & 201 & 0.25 \\
\hline \multirow[t]{2}{*}{ SYp5 } & $5.3-5.5$ & B3 & 6 & 55 & 61 & 0.11 \\
\hline & $5.5-7.5$ & B3 & 37 & 24 & 61 & 1.54 \\
\hline \multirow[t]{2}{*}{ SYp4 } & $7.5-8.2$ & B2 & 9 & 6 & 15 & 1.50 \\
\hline & $8.2-9.8$ & B2 & 4 & 11 & 15 & 0.36 \\
\hline \multicolumn{7}{|l|}{ SYp3 } \\
\hline $\mathrm{b}$ & $9.8-10.4$ & B1 & 31 & 46 & 77 & 0.67 \\
\hline $\mathrm{a}$ & $10.4-11.5$ & $\mathrm{D} 3+\mathrm{B} 1$ & 31 & 52 & 83 & 0.60 \\
\hline SYp2 & $11.5-13.7$ & $\mathrm{~T} 1+\mathrm{D} 2+\mathrm{B} 1$ & 31 & 65 & 96 & 0.48 \\
\hline SYp1 & $13.7-15.0$ & D1 & 8 & 19 & 27 & 0.42 \\
\hline
\end{tabular}

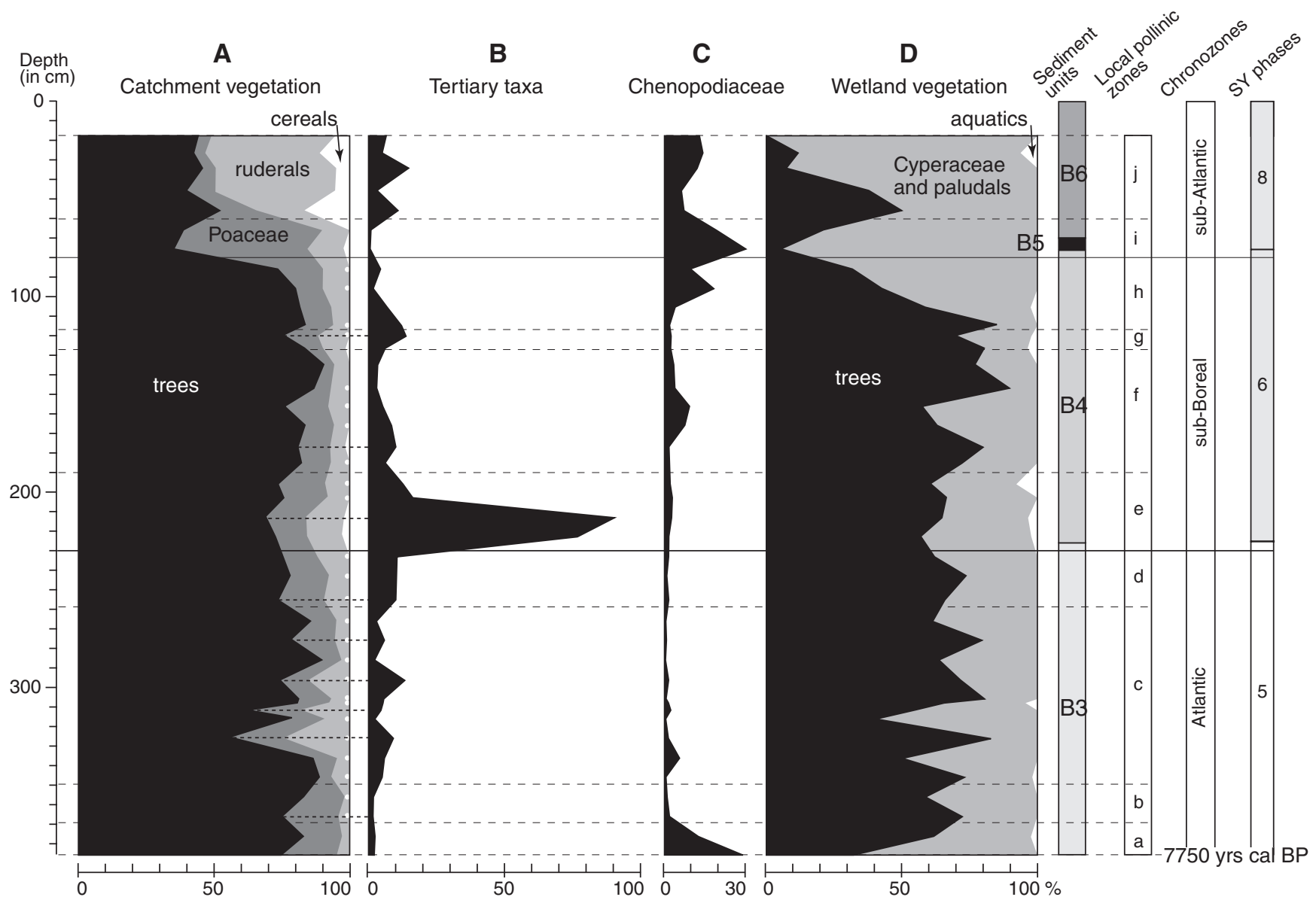

Figure 7. Pollen diagrams from $P$ core (location, see Figure 4B). (A) Catchment vegetation as per cent of total catchment taxa. Trees: Corylus, Quercus, Ulmus, Tilia, Betula, Fagus, Abies, Juniperus, Hedera, Acer, Picea, Pinus. Ruderals (except Chenopodiaceae): Artemisia, Asteraceae, Carduns, Centaurea, Cuscuta, Brassicaceae, Cichorioideae, Convolvulaceae, Caryophyllaceae, Malvaceae, Apiaceae, Plantago, Rumex, Rubiaceae, Fabaceae, Lamiaceae, Urticaceae, Polygonum. (B) Tertiary taxa as per cent of total pollen grains. (C) Chenopodiaceae as per cent of total pollen grains. (D) Wetland vegetation as per cent of total wetland taxa. Trees: Alnus, Salix, Fraxinus, Ligustrum, Viburnum, Myrica, Sambucus, Vitis. Cyperaceae and paludals: Filipendula, Thalictrum, Typhaceae. Aquatics: Potamogeton, Lemna

endorheic conditions (Einsele and Hinderer, 1998) which were continuous until the beginning of the Atlantic and then intermittent until the beginning of the sub-Boreal (Bréhéret et al., 2003, 2008; Fourmont et al., 2006). During the late Holocene (SYp6 and 8), the fact that only precipitated low-Mg calcite is found in sediments is the consequence of open conditions - an extensive freshwater lake with fluctuating water level, as shown by non-pollinic microfossils (Argant and Lopez-Saez, 2004), and probable frequent 


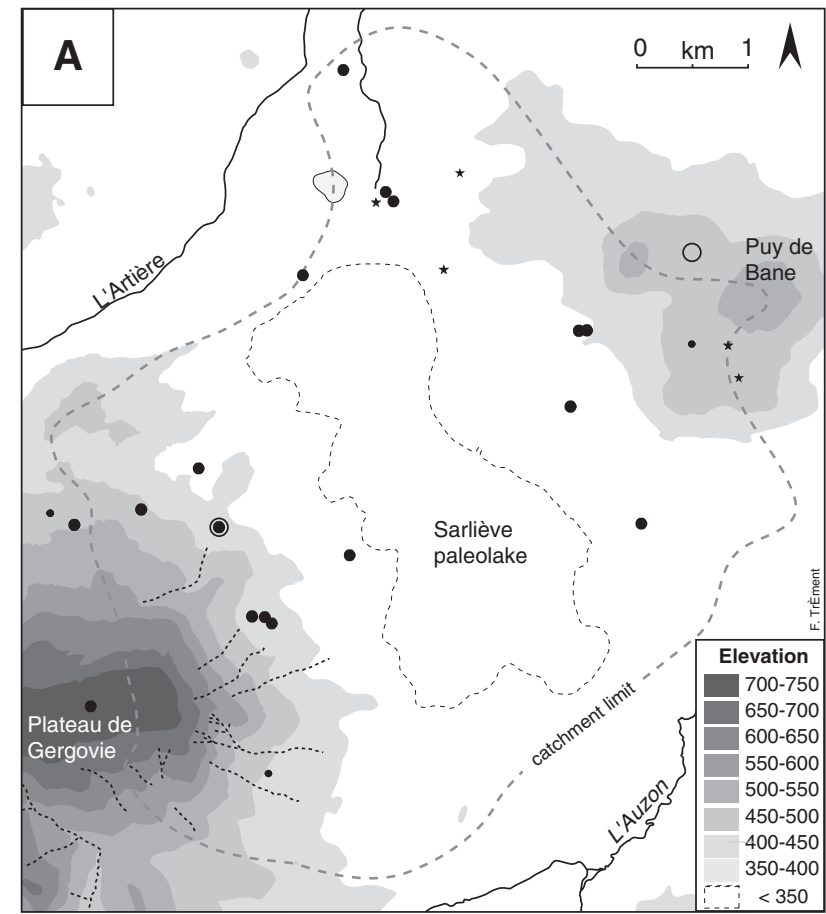

Ancient Neolithic: O Probable site

Middle Neolithic: • Site • Probable site * Isolated artefact

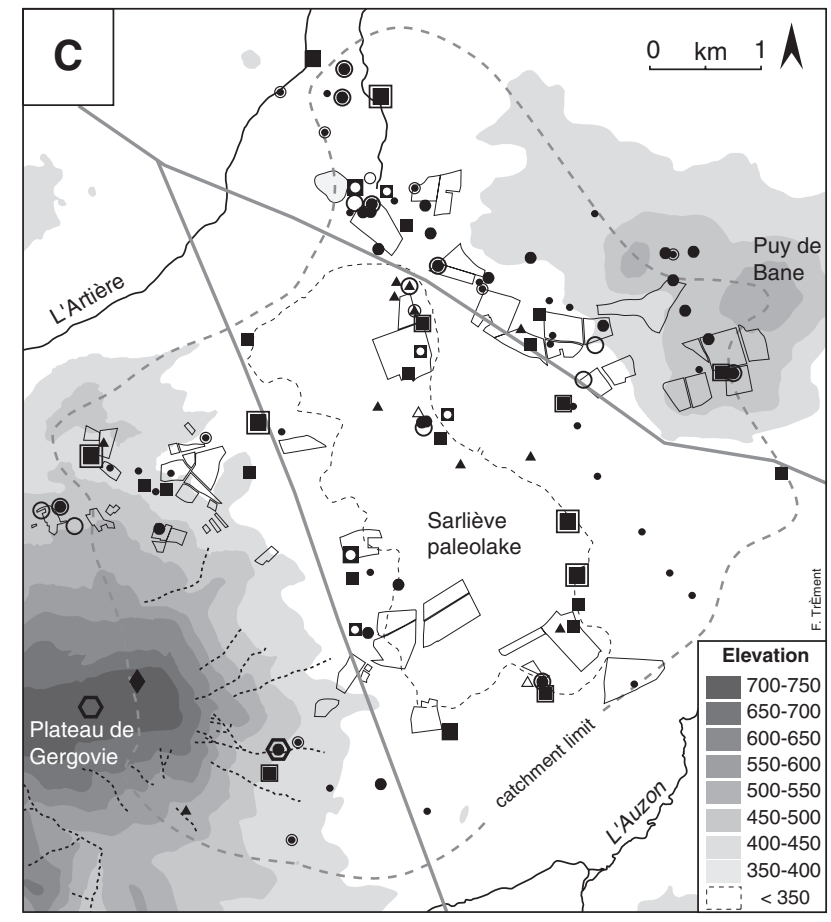

Final La Tène:

$\square$ Agglomeration $\square \square \bigcirc$ Site $\bigcirc$ Probable site $\Delta$ Funerary site

Early Roman Empire:

$\begin{array}{lll}\text { - Large villa } & \text { Darge villa with Final La Tène traces } \star \text { Isolated artefact } \\ \text { - Small villa } & \text { a Small villa with Final La Tène traces }- \text { Roman road } \\ \text { - Site } & \text { - Probable site } & \square \text { Off-site pottery } \\ \text { - Sanctuary } & \text { - Funerary site }\end{array}$

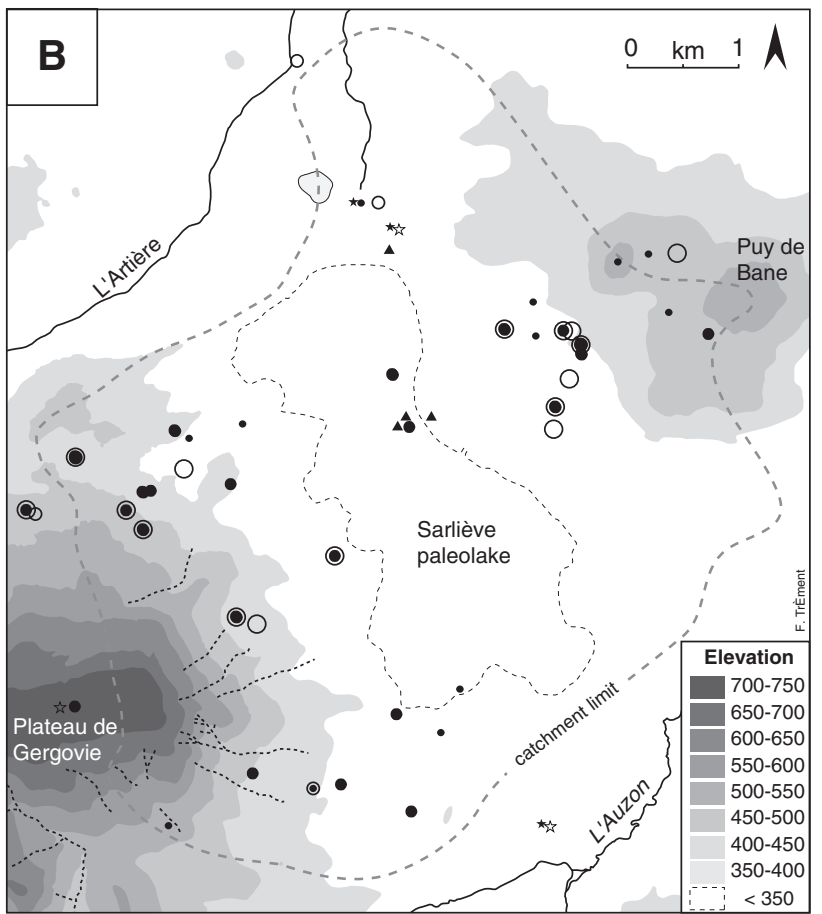

Ancient and Middle Bronze Ages:

O Site O Probable site \&s Isolated artefact Final Bronze Ages until Ancient La Tène: • Site • Probable site * Isolated artefact A Funerary site

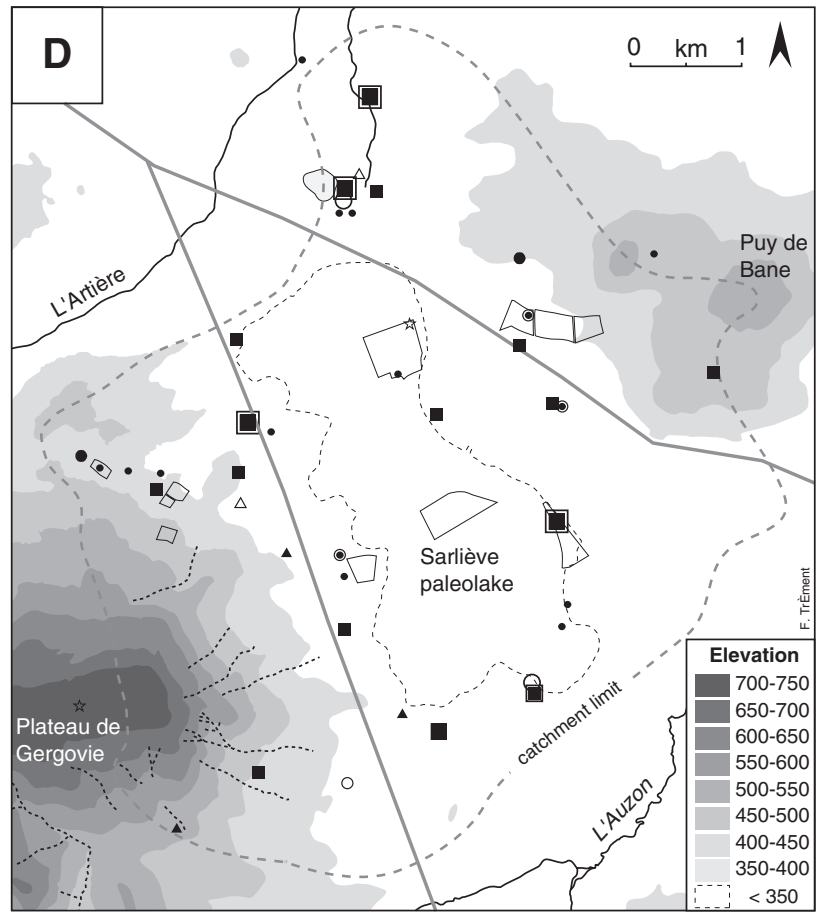

Late Roman Empire:

- Large villa $\quad$ Small villa - Site - Probable site \& Funerary site
- Roman road $\square$ Off-site pottery

Early Middle Ages:

$\square \square \bigcirc$ Site $\quad \circ$ Probable site $\triangle$ Funerary site it Isolated artefact

Figure 8. Location maps of human settlements in Sarliève catchment at different periods. (A) Ancient and middle Neolithic; (B) Bronze Ages up to ancient La Tène; (C) final La Tène and early Roman Empire; (D) late Roman Empire and early Middle Ages

outflow and loss of solid matter downstream of the lake during highstand periods. Although sediment storage increased markedly at this time (Table 1), SY may be slightly underestimated. Very abundant slope formations ( $74.5 \%$ of catchment area: Figure 5B) are mainly due to periglacial processes (rock fall, solifluxion: Jeambrun et al., 1973) and thus prior to lake formation. Colluvium 
A

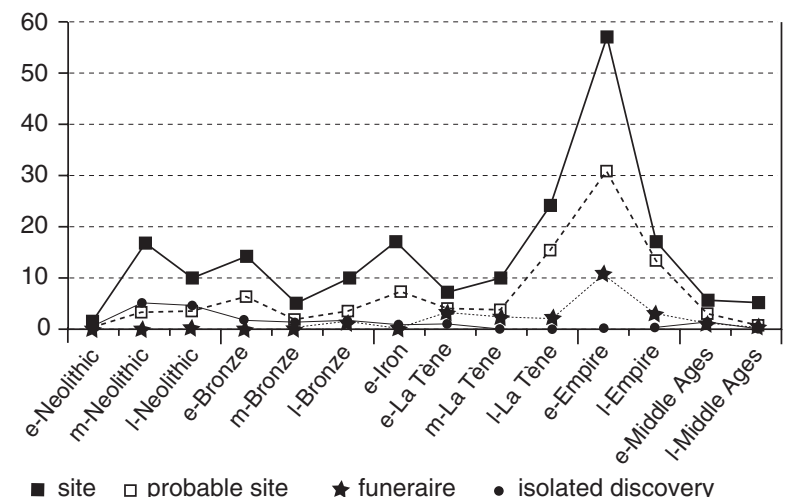

- site $\square$ probable site $\star$ funeraire • isolated discovery

B

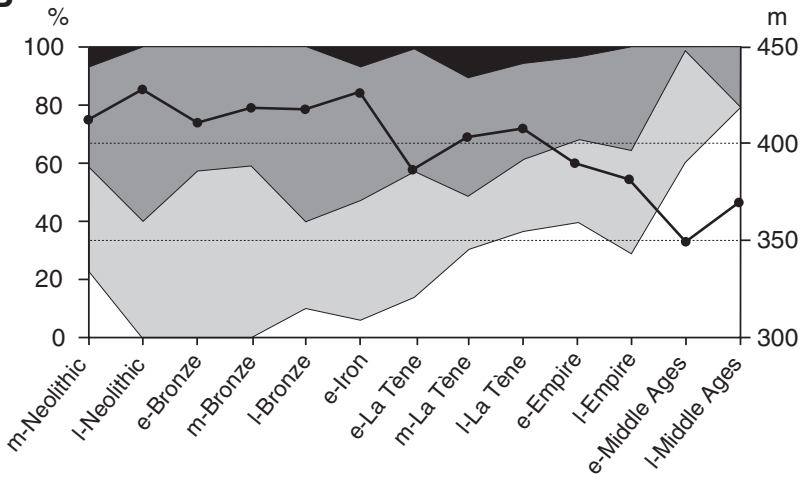

elevation $(m)$

$>500$

$400-500$

$350-400$

mean elevation $(\mathrm{m})$

C ha

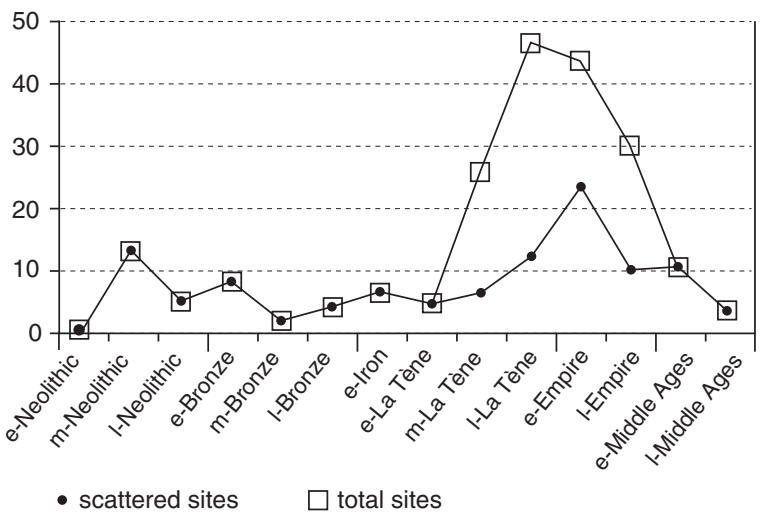

Figure 9. Stastistics of archaeological sites by period. e, early; $\mathrm{m}$, middle; 1, late. (A) Site numbers; (B) abundance of sites as per cent of elevation class, and mean elevation of sites in metres; (C) cumulated surface area of sites in ha

rich in organic matter containing archaeological artefacts (Vernet et al., 2005) and clearly the result of Holocene soil erosion, is mainly located on the edge of the palaeolake. As it is not widespread in the catchment, it was not quantified.

Evaluating real DSY rates is difficult because of high discharge of dissolved matter downstream of the lake during high-water periods (Fourmont et al., 2009). DSY rates during the Lateglacial and early Holocene (SYp1 to SYp4) are probably close to gross rates resulting from the endorheic conditions of the palaeolake (Einsele and Hinderer, 1998). During the middle and particularly the late Holocene, because the basin was open more often, first for short periods (SYp5), then more continuously (SYp6 and 8) when the palaeolake spread out and detritism increased, DSY rates are probably grossly underestimated, although they were high during the sub-Boreal and sub-Atlantic (Figure 6C).

The Sarliève catchment is located in medium-sized mountains where slope gradients are low $\left(<5^{\circ}\right.$ for $60 \%$ of the catchment area; Figure 5) and carbonated rocks dominate (about $75 \%$ of the area; Figure 1B). SSY and DSY rates for the most recent period (178 to 203 and $44 \mathrm{t} / \mathrm{km}^{2}$ per yr, respectively for SYp8) are a little higher than those assessed from current river flux (Meybeck, 1979; Milliman and Meade, 1983) and as high as soil erosion rates (Cerdan et al., 2006) in similar physiographic and bioclimatic environments. Nevertheless, because of the climate characteristics of the Sarliève environment, lower rates could be expected. This suggests that SY rates calculated from Sarliève sediment stores, although minimum, are quite close to gross erosion rates.

Sediment yield is mainly related to soil erosion. Assuming that the mean volumetric mass of eroded soils is $2 \mathrm{~g} / \mathrm{cm}^{3}$, it is possible to converted the sediment yield (in $\mathrm{t} / \mathrm{km}^{2}$ per yr) in catchment-soil erosion rates (in $\mathrm{mm} / \mathrm{yr}$ ). During SYp1 to 5 as there is no colluvium of this time on slopes and SY calculated values are close to true sediment flux values, we assumed that SY rates correspond to erosion rates. During SYp6 and 8, because of colluvium stores on slopes and matter delivery downstream the lake, erosion rates deduced from SSY rates are evidently underestimated, especially DSY.

During the Lateglacial and Holocene, TSY, SSY and DSY varied greatly (Figure 6). Examination of archaeological and palynological data provides clear indication of two periods in the evolution of the palaeoenvironment: the first before $7500 \mathrm{yr}$ cal. BP during which SY was due only to natural bioclimatic conditions (SYp1 to 4), and the second, after this date, during which SY was also due to human impact (SYp5 to 9).

\section{Sediment yield evolution before evidence of human impact (Lateglacial and early Holocene)}

While there is evidence of human settlement in the Sarliève catchment prior to the Neolithic, it is sparse (Pomel, 1853; Pommerol, 1877; Trément et al., 2007b). Palynological data show no evidence of farming before the Atlantic (Gachon, 1963): cereals only appear in pollinic zone $b$ (Figure 7A). Although ruderals were present from the beginning of the Atlantic, it is likely that variations in vegetation and hydrological processes influencing erosion prior to about $7500 \mathrm{yr}$ cal. BP were only due to natural processes and climate change. During the Lateglacial and early Holocene, TSY was lower (mean $55 \mathrm{t} / \mathrm{km}^{2}$ per yr) than subsequently, but variable (Figures 6A and 10): from 6 to $65 \mathrm{t} / \mathrm{km}^{2}$ per yr for SSY and 4 to 31 $\mathrm{t} / \mathrm{km}^{2}$ per yr for DSY, with a DSY/SSY ratio of about 0.5 .

\section{Sediment yield phase 1 (SYp1)}

During SYp1 (Bölling and beginning of the Alleröd), very low SSY and DSY rates could be due to the first postglacial development of arboreal cover with Juniperus and Betula (de Beaulieu et al., 1988) which limited mechanical and chemical erosion during a cool period (Johnsen et al., 1992 ).

\section{Sediment yield phase 2 (SYp2)}

Increased SSY (65 t/km² per yr) during the Alleröd at $13700 \mathrm{yr}$ cal. $\mathrm{BP}$, despite the continuation of previous bioclimatic conditions, 
Sediment yield rates

Chronology

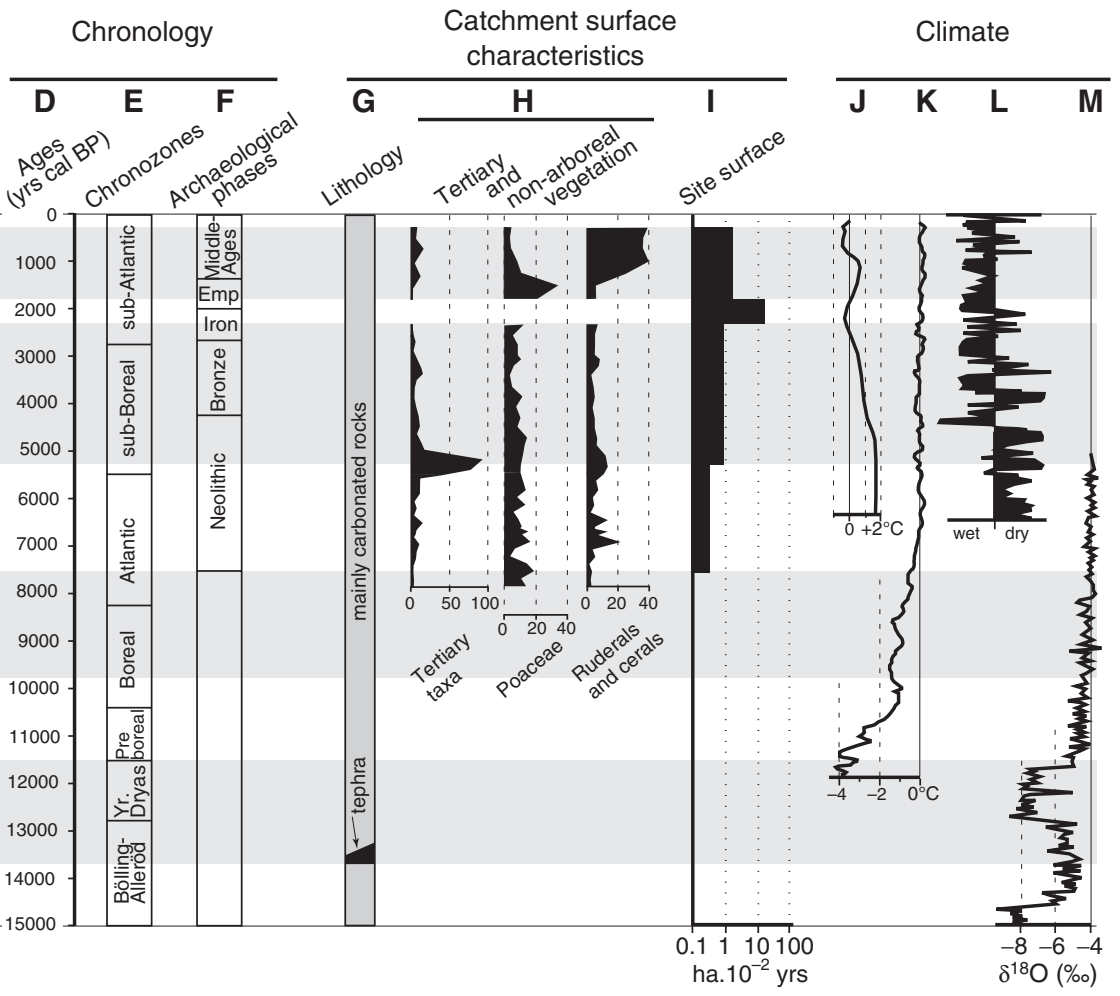

\begin{tabular}{ccc}
\hline A & B & C \\
SY & Solid & Dissolved \\
phases & & \\
\hline SYp & &
\end{tabular}
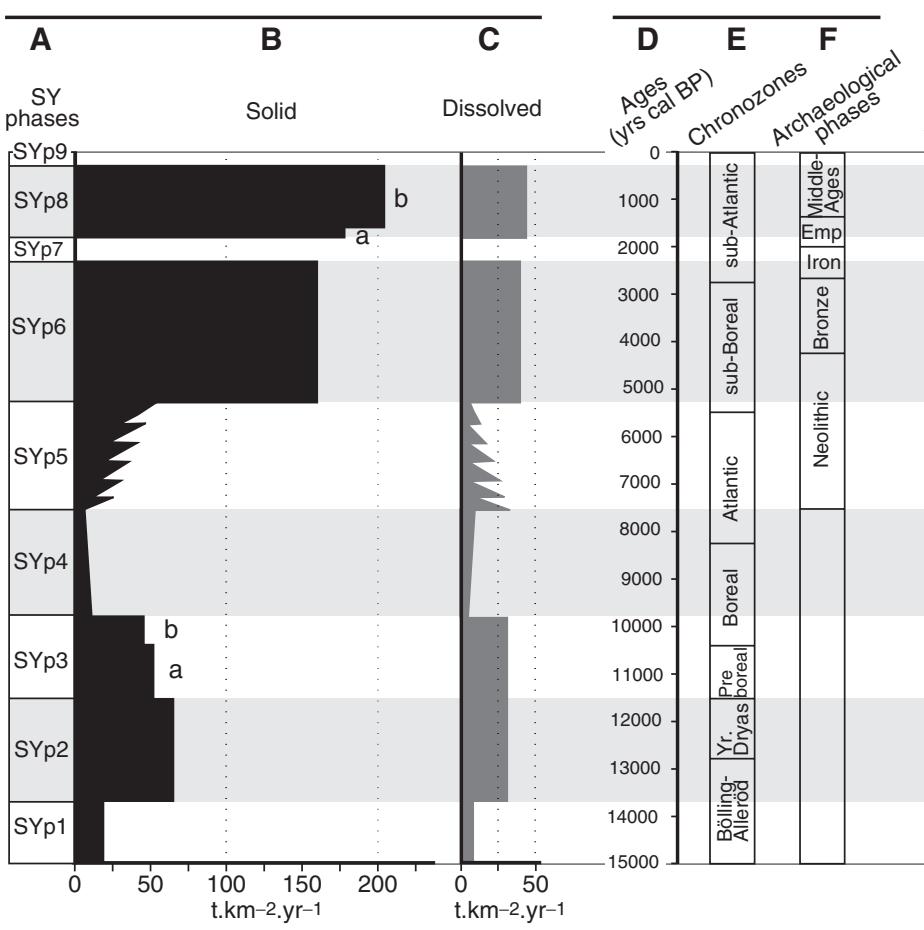

Figure 10. Comparison of sediment yield rates, chronology, catchment area characteristics and climate. (D) Ages in yr cal. BP; (H) tertiary taxa as per cent of total pollen grains; Poaceae, and ruderals and cereals as per cent of catchment-taxa pollen-grains; (J) temperature from Greenland ice-core (Johnsen et al., 2001); (K) temperature from pollen data (Davis et al., 2003); (L) humidity from bog (Barber et al., 1994); (M) temperature from lake record (von Grafenstein et al., 1999)

seems to be due to CF1 tephra fallout, with a mean depth of $15 \mathrm{~cm}$ (Vernet and Raynal, 2000). Tephric cover could have favoured mechanical erosion over several decades or centuries (Figure 10G) because of the temporary destruction of vegetation dominated by Betula and Pinus on slopes (de Beaulieu et al., 1988), but mainly because of the high susceptibility of tephra to mechanical erosion (Chorley et al., 1984; Collins and Dunne, 1986). Likewise, increased DSY (31 t/ $\mathrm{km}^{2}$ per yr) can be explained by high susceptibility to dissolution of tephra silicates, mainly glass (Fourmont et al., 2006). These higher SSY and DSY rates continued during the Younger Dryas up to about $11500 \mathrm{yr}$ cal. BP, although tephric cover had probably been completely eroded by that time; Tertiary pollen-grain abundance in lacustrine sediments (Gachon, 1963) shows that mechanical erosion mainly cut into the Oligocene bedrock. During the cold and dry Younger Dryas (Peteet, 1995; Anderson, 1997) (Figure 10M) mechanical erosion was favoured by tundra (de Beaulieu et al., 1988), which does not provide efficient protection of the earth surface against erosion, as observed in the Lac Chambon catchment located in a granitic and volcanic area close to the Sarliève catchment (Macaire et al., 1995, 1997). Nevertheless, high DSY indicates that the climate was fairly humid, and the dissolution of carbonated rocks could have been favoured by the cold climate.

\section{Sediment yield phase 3 (SYp3)}

At the beginning of the Holocene, between $11500 \mathrm{yr}$ cal. BP and $9800 \mathrm{yr}$ cal. BP, SSY and DSY remained high, although the former fell to $46 \mathrm{t} / \mathrm{km}^{2}$ per $\mathrm{yr}$ (Ep3b). At this time, forest developed, dominated first by Corylus and then Quercus and Ulmus (Gachon, 1963; de Beaulieu et al., 1988), and the climate became warmer
(Johnsen et al., 2001; Davis et al., 2003) (Figure 10K,M). Gachon (1963) suggested that the abundance of Chenopodiaceae pollen grains in Sarliève sediments during the Lateglacial and early Holocene could have been due to slope-mass movement by solifluction, which could have contributed to the development of these pioneering taxa. The abundance of Chenopodiaceae at the beginning of the Atlantic (zone a, Figure 7C), when SSY was very low $\left(6 \mathrm{t} / \mathrm{km}^{2}\right.$ per yr), indicates that there is no relationship between the abundance of this taxa and the intensity of mechanical erosion. On the other hand, Chenopodiaceae could have colonized the bottom of the lacustrine depression during drought periods, providing evidence of the presence of salt water as shown elsewhere by Valero-Garcés et al. (2000). Salt, also testified by precipitated minerals in B1 to B3 lacustrine units (Fourmont et al., 2006; Bréhéret et al., 2008), was produced by dissolution of gypsum forming a small part of Oligocene limestones and marls (Jeambrun et al., 1973). Dissolution of catchment bedrock gypsum and calcite during SYp3 could indicate the beginning of pedogenesis during the early Holocene and is in accordance with a relatively high value of DSY (31 t/ $\mathrm{km}^{2}$ per yr). However, it was not possible to evaluate precisely the evolution of DSY rates from SYp2 to SYp3.

\section{Sediment yield phase 4 (SYp4)}

During the Boreal and the Atlantic before $7500 \mathrm{yr}$ cal. BP, erosion rates, much lower than before and similar to SYp1, did not change significantly (SSY $=6$ to $11 \mathrm{t} / \mathrm{km}^{2}$ per yr and DSY $=4$ to $9 \mathrm{t} / \mathrm{km}^{2}$ per $\mathrm{yr}$ ), although the DSY/SSY ratio increased ( 0.36 to 1.50 ; Figure 6D). This trend could be explained by extensive development of forest cover, dominated by Corylus and Quercus (de Beaulieu et al., 1988; Gachon, 1963), related to climate warming 
(Figure 10K,M), which provided efficient protection of the earth surface against mechanical erosion. Higher temperatures and less precipitation during the Boreal, testified in western Europe (Andrews, 2006) with minimum temperatures and dryness at about 8200 yr cal. BP in the Northern Hemisphere (Carrion, 2002; Alley and Agustsdottir, 2005; Macklin et al., 2006), may have been more marked in the drier microclimate of Sarliève and could explain the low absolute value of DSY. Nevertheless, the sharp rise of the DSY/SSY ratio at this period, marked by catchmentslope stability, indicates a matter budget promoting an increase in soil depth.

\section{Sediment yield evolution during periods of human impact (middle and late Holocene)}

TSY increased dramatically after $7500 \mathrm{yr}$ cal. BP (average for SYp5, SYp6 and SYp8: $165 \mathrm{t} / \mathrm{km}^{2}$ per yr): from 24 to $232 \mathrm{t} / \mathrm{km}^{2}$ per yr for SSY and from 6 to $44 \mathrm{t} / \mathrm{km}^{2}$ per yr for DSY. The DSY/SSY ratio decreased to close to 0.25 , with considerable fluctuations during the Atlantic (SYp5) (Figure 6). This rise in sediment yield rate appeared concomitantly with the growth of human settlement in the Sarliève catchment (Figure 10I). Pottery dated from the end of the Ancient Neolithic, although scarce (two probable sites), provides evidence of human activity in the catchment; similar activity has also been observed in many places around ClermontFerrand from 7500 yr cal. BP (Georjon et al., 2004; Pouenat, 2007). Human activity increased considerably after that period, with some fluctuations (Figures 8 and 9). Evidence of ruderals (zone a, Figure7A) and cereals (zone b, Figure 7A) from the beginning of the Atlantic show that vegetation and earth surface conditions were modified by human activities from about $7500 \mathrm{yr}$ BP. Human activity and climate together influenced erosion processes and intensity (Figure 10H-L).

\section{Sediment yield phase 5 (SYp5)}

From the Atlantic after $7500 \mathrm{yr}$ cal. BP to the beginning of the sub-Boreal at about $5300 \mathrm{yr}$ cal. BP, sharp TSY increase $\left(61 \mathrm{t} / \mathrm{km}^{2}\right.$ per yr) is characterized by strong variations in DSY/SSY ratio. Marked SSY increase (by a factor of nine maximum relative to SYp4) together with lower variation in DSY (increase by a factor of four maximum) is an indication of human impact (Dearing and Jones, 2003), although climate became a little more humid than before. SYp5 corresponds to the development of the Neolithic society and arable farming in the Massif Central (Georjon et al., 2004), particularly widespread in the Sarliève catchment during the Chassean Middle Neolithic (Figures 8A, 9A). Evidence of farming is provided by cereal pollen grains (Figure 7A). Farming seems to have occurred mainly at elevations of 350 to $500 \mathrm{~m}$ (average 400-450 m, Figure 9B) where ancient and middle Neolithic sites cover a total area of about 13 ha (Figure 9C), corresponding to a mean time-weighted settlement area of 0.65 ha per century (Figure 10I). It is difficult to explain high variations of arboreal pollen grain contents in slope vegetation during the Atlantic (zones a, b and c Figure 7A) by climate change, which, although not marked, did occur (Aaby, 1976; Bond et al., 2001; Douglas et al., 2007). On the other hand, a sharp increase in ruderals (Figure 7A) and preferential decrease in Corylus (Figure 11B), which is more easily cut than Quercus (Figure 11A), during periods of slope arboreal pollen regression, could indicate human impact on deforestation. This seems to be confirmed by frequent simultaneity between periods of deforestation and periods of high Tertiary pollen grain content (Figure 7B) and detrital layer deposition (HCS facies in B3), indicating increased mechanical erosion. In the lacustrine depression during SYp5, a marked variation of arboreal pollen contents (mainly Alnus) compared to Cyperaceae and paludals (Figure 7D), appears to be related to an alternation of biochemical dominated BL facies and low water level in the palaeolake on the one hand, and detrital dominated HCS facies and high water level observed in lacustrine sediments on the other (Fourmont et al., 2009). Non-pollinic microfossils indicate the occurrence of livestock farming as early as pollinic zone c, which could explain the mesotrophic to eutrophic character of the palaeolake waters (Argant and Lopez-Saez, 2004). These marked variations in vegetation, hydrology and sediment supply in the lacustrine depression are similar to variations in the catchment vegetation. Low water level in the lake could be the result of increased evapotranspiration during afforestation in the catchment, and high water level due to increased runoff during deforestation. However, the relative impacts of climate versus human activity on hydrology and sediment yield are not yet clear because of the marked variability of sedimentary facies in unit B3. High resolution multiproxy analysis (at a centimetric scale) of this unit is in progress.

\section{Sediment yield phase 6 (SYp6)}

From the sub-Boreal after $5300 \mathrm{yr}$ cal. BP up to $2300 \mathrm{yr}$ cal. BP in the sub-Atlantic, increased TSY $\left(201 \mathrm{t} / \mathrm{km}^{2}\right.$ per $\left.\mathrm{yr}\right)$ and rising water level (Fourmont et al., 2009) are in keeping with changes in the climate which became more humid between $5200 \mathrm{yr}$ cal. BP and $4500 \mathrm{yr}$ cal. BP (Barber et al., 1994; Magny et al., 2006) and cooler (Johnsen et al., 2001), with greater cooling at about 2800 yr cal. BP (van Geel et al., 1998) (Figure 10J,L). Nevertheless, a greater rise in SSY and DSY during SYp6 than SYp5 (by factors of 2.9 and 6.6, respectively, Figures $6 \mathrm{~B}$ and C) cannot be explained solely by climate change which was not marked. The rise in SSY is synchronous with increased human settlement between the end of the Neolithic and the ancient La Tène as shown by the abundance of sites, particularly during the ancient Bronze Age, final Bronze Age and first Iron Age (Figures 8B and 9A): total surface area of sites varies between archaeological periods (Figure 9C), but the mean time-weighted site area increased more during SYp6 (0.92 ha/century) than SYp5 (0.65) (Figure 10I). These sites, located at elevations between 350 and $500 \mathrm{~m}$ from the final Neolithic until the middle La Tène (Figure 9C), were scattered between $700 \mathrm{~m}$ and the edge of the palaeolake $(<350 \mathrm{~m})$ from the final Bronze until the middle La Tène, promoting transit of solid flux from top to bottom of slopes. During SYp6, forest cover on slopes, marked by the replacement of Corylus by Fagus (zones e to h, Figure 7A) was more continuous than during SYp5. Nevertheless, several maximum cereal-pollen contents, often synchronous with increased Tertiary taxa and slight forest regression (Figure 7A, B), show that human impact and mechanical erosion of bedrock could have been intense during certain periods (pollinic zone e in particular). These periods could correspond to rapid human population growth, as during the ancient Bronze Age (pollinic zone e) and ancient Iron Age (zone g) and explain the high overall SSY value during SYp6. The palaeolake water level, which was probably higher because of the more humid climate, varied as shown by non-pollinic microfossils (Argant and Lopez-Saez, 2004). At the edge of the palaeolake, where vegetation varied 


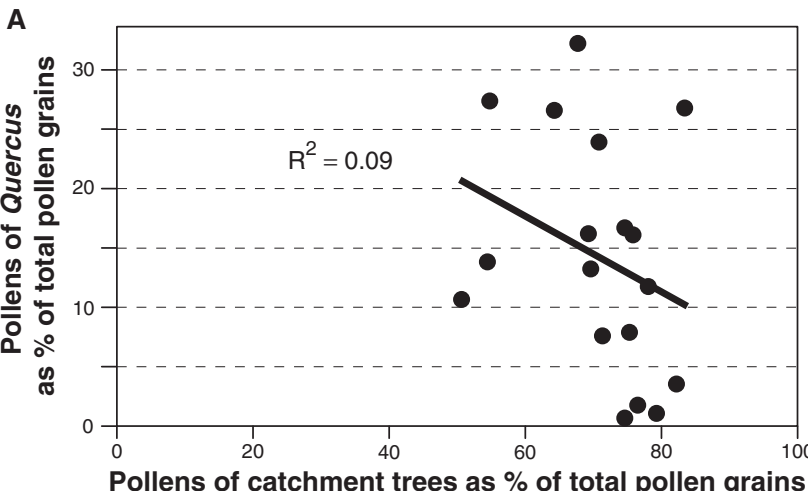

Pollens of catchment trees as $\%$ of total pollen grains

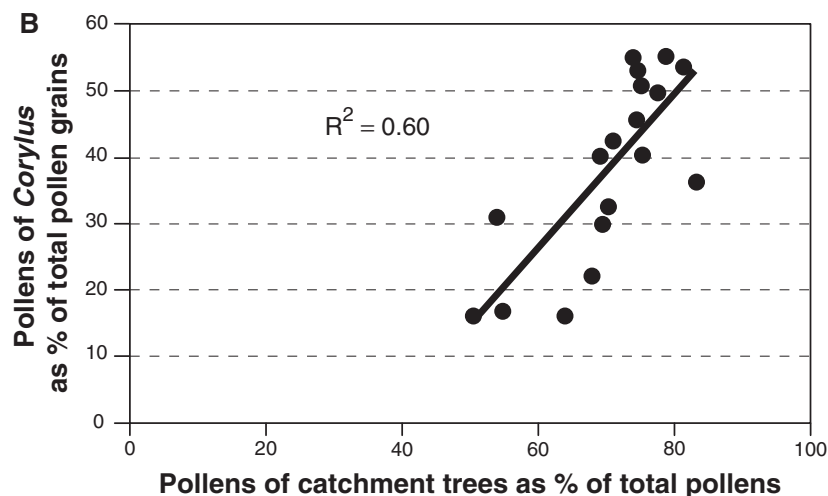

Figure 11. Correlations between catchment arboreal taxa from total pollen grain percentages. (A) Quercus versus catchment trees; (B) Corylus versus catchment trees

more than on catchment slopes (Figure 7D), periods of Cyperaceae and paludal increase and arboreal taxa decrease can be explained by frequent variations in water level, recently emerged areas being colonized by hygrophilous herbs. Nevertheless, Cyperaceae probably indicate above all the occasional but increasing deforestation of the edge of the palaeolake by humans during SYp6, especially during the ancient La Tène (Figure 9B,C, and zone h Figure 7D), a period of extensive human settlement confirmed by increasing eutrophication of palaeolake water and evidence of livestock farming (Argant and Lopez-Saez, 2004). Periods of high deforestation round the palaeolake do not seem to be synchronous with that on catchment slopes (Figure 7A, D), indicating possible differences in land use from one area to another; as a result, matter produced by mechanical erosion could have moved spasmodically toward the lake.

Although calcite dissolution is favoured by a humid climate, the very high increase in DSY during SYp6 cannot be explained only by climate change. Dissolved matter is mainly composed of carbonate ions because of weathering of marly-calcareous bedrock. It is probable that strong soil rejuvenation by mechanical erosion reactivated the weathering of parent-rocks, and thus DSY, as suggested by Carson and Kirkby (1972) and observed in the nearby Chambon catchment by Gay and Macaire (1999). Low DSY/SSY ratio (\# 0.25) expresses this imbalance in soil evolution.

\section{Sediment yield phase 7 (SYp7)}

It is not possible to evaluate sediment yield rates during SYp7, corresponding to the middle and final $\mathrm{La}$ Tène and the early Roman Empire (2300-1800 yr cal. BP), because there are no sediment stores dating from these periods. Archaeological evidence such as drainage ditches, buildings, funerary sites, and off-site pottery for soil enrichment observed at the bottom of the lacustrine depression show that it was dry and mainly settled by humans at the end of the La Tène and during the early Roman Empire (Figure 8C). These dry conditions could have been partly due to a less humid climate at this time (Barber et al., 1994; Magny, 2004) (Figure 10L), but were mainly the result of human activity as shown by drainage ditches and parcels with boundary markings in the depression (Trément et al., 2007b). A marked rise in settlements on catchment slopes is shown by very abundant sites of the La Tène and early Roman Empire (Figure 9A), especially at low elevations (Figure 9B), and the high value of time-weighted surface area of sites (21 ha/century) (Figures 9C and 10I). Archaeological data (Trément et al., 2007b) and the increasing extent of enriched soils (Figure 8C) indicate intense arable farming, suggesting a high erosion rate. The lack of deposits is due to the discharge of most solid and dissolved matter downstream of the catchment through efficient drainage ditches.

\section{Sediment yield phase 8 (SYp8)}

During the sub-Atlantic, from $1800 \mathrm{yr}$ cal. BP until $300 \mathrm{yr}$ cal. BP, TSY (222 to $247 \mathrm{t} / \mathrm{km}^{2}$ per yr) increased slightly relative to SYp6 (by a factor of 1.1 to 1.2) (Figure 6A). After the great development of the final La Tène and early Roman Empire societies (SYp7), similar SY rates could be explained by a sharp reduction in the number and total surface area of sites (time-weighted surface area $=3.5 \mathrm{ha}$ /century) during the late Roman Empire and early Middle Ages (Figures 8D and 9A,C), down to rates close to those for SYp6. Nevertheless, during SYp8, there was a marked decrease in Pinus-dominated forest on slopes (less than $50 \%$ of arboreal pollen grains, Figure 7A). Moreover, the increase in Chenopodiaceae initiated during the La Tène (Figure 7C) cannot be attributed to water salinity, as during the Lateglacial and early Holocene, within the context of high water levels and greater humidity, particularly during the last millenium (Barber et al., 1994; Magny, 2004; Magny et al., 2008) (Figure 10L); this taxa, with the increase in other ruderals, more likely indicates a strong anthropogenic impact on vegetation. The presence of pyrofusinite-type charcoal fragments (Fourmont, 2005) and fungi growing on charred tissue (Argant and Lopez-Saez, 2004) in black clayeysilty B5 unit, are also evidence of frequent fires during the late Roman Empire, probably for soil enrichment rather than due to forest clearing for farming which was already extensive. The deforested area was first colonized by grassland (zone 1, Figure 7A) for livestock as shown by coprophilous fungi and evidence of palaeolake eutrophication. Despite this high anthropogenic impact on vegetation, low SSY increase during the late Roman Empire (SYp8a) could be explained by the development of grassland at different slope elevations (Figure 9B) down to the edge of the palaeolake where trees almost disappeared (Figure 7D); pastureland provides efficient protection of the earth surface against mechanical erosion, except when overgrazed (Ursic and Dendy, 1965; Pimentel et al., 1995; Hooke, 2000).

From the beginning of the Middle Ages, croplands developed on catchment slopes, as shown by increased cereal and fallow-land taxa (zone j, Figure 7A), while palaeolake eutrophication was at its highest (Argant and Lopez-Saez, 2004). Settlement sites, less numerous and extended than before, were concentrated around the palaeolake (Figures 8D and 9B). During SYp8b (the Middle Ages 
and Modern Times), high SSY (203 $\mathrm{t} / \mathrm{km}^{2}$ per yr) mainly due to mechanical erosion of sandy-gravelly sediments from the alluvial terrace east of the palaeolake (Figure 1), which produced D8 deltaic unit, could be the result of agricultural concentration in this area. Moreover, colluvium overlying archaeological sites of the late Roman Empire and early Middle Ages at the slope bottom indicates increased mechanical erosion after these periods. This colluvium storage could have been promoted by temporary afforestation (Alnus) round the palaeolake (first part of zone j, Figure 7D). These colluvium stores were not taken into account when quantifying SYp8b SSY which is thus underestimated. Rates of DSY (minimum of $44 \mathrm{t} / \mathrm{km}^{2}$ per yr) and the DSY/SSY ratio (\# 0.25) do not differ much from SYp6 rates, showing similar pedogenetic conditions with high soil rejuvenation by mechanical erosion.

\section{Sediment yield phase 9 (SYp9)}

SY cannot be evaluated for the last three centuries as sediment yield has been discharged downstream of the Sarliève catchment through ditches, called 'rases', since the palaeolake was drained during the seventeenth century (Fournier, 1996).

\section{Balance of climate change versus human impact on sediment yield, earth surface lowering and soil evolution}

During the Lateglacial and early Holocene (SYp1 to SYp4), SSY and DSY rates, lower on average than later, depended mainly on strong climate change, from cold to warm, with a general trend towards dryness (Figure 10). Highest SSY rates (SYp2 and SYp3) correspond to the coldest periods (essentially the Younger Dryas and Preboreal), while lowest rates (SYp1 and SYp4) correspond to vegetation development during warmer periods (Bölling-Alleröd and Boreal). These erosion trends are similar to those observed in the Lac Chambon catchment (Macaire et al., 1997; Gay and Macaire, 1999), located close to the Sarliève catchment but at a higher elevation and in a crystalline bedrock area, confirming regional climate impact on sediment yield. The trend in SSY values at Sarliève differs from that observed in mountainous areas where abundant inherited glacial deposits induced high SSY after glacier retreat (Church and Ryder, 1972; Bichet et al., 1999; Hinderer, 2001). However, in the Sarliève catchment, climatic impact on SYwas disturbed by CF1 tephra fallout at $13700 \mathrm{yr}$ cal. BP, leading to increased SSY from the Alleröd, before the climate change of the Younger Dryas, confirming strong and short-term impact of surface formations on mechanical erosion. The trend in DSY values is fairly similar to SSY (Figure 10B and C), with an increase during cold periods. However, temperature, relative to precipitation, is not the main factor of carbonate dissolution (Gombert, 1997), and the similar DSY and SSY trends suggest that mechanical erosion favoured chemical erosion through soil rejuvenation, so that parent-rocks, which are more susceptible to dissolution, were found close to the earth surface (Carson and Kirkby, 1972; Berner and Berner, 1987; Gabet and Mudd, 2009); carbonated rocks, and temporarily tephra, were particularly reactive to this process.

During the late Holocene (SYp6 and SYp8), increasing SSY and DSY are in keeping with lower temperatures and rising precipitation after 5200 yr cal. BP (Johnsen et al., 2001; Barber et al., 1994). However, SSY and DSY during the Holocene (SYp4-SYp8), when there was no marked climate change, varied extensively (by factors of $>38$ and $>11$, respectively), while they varied less (by factors of 11 and 8, respectively) during the Lateglacial and early Holocene (SYp2-SYp4) which was marked by considerable climate change. Thus, increased SYrates during SYp6 and SYp8, particularly SSY, seem to be highly related to the growth of human activity.

SSY (174 t/ $\mathrm{km}^{2}$ per yr on average for SYp6 and SYp8) rose by a factor of 6.4 (i.e. 540\%) during the late Holocene compared with earlier Holocene periods $\left(27 \mathrm{t} / \mathrm{km}^{2}\right.$ per yr on average for SYp3 to SYp5), while precipitation is assumed to have risen by $50 \mathrm{~mm}$ to $100 \mathrm{~mm}$ (Guiot et al., 1989), i.e. about 10\%, during the sub-Boreal and sub-Atlantic. Any increase in rainfall may directly exacerbate erosion (Boardman, 1990; Bullock, 1991), but the relationship between these two factors is not linear: a $10 \%$ increase in winter rainfall can induce an increase in mechanical erosion of up to $150 \%$ (Favis-Mortlock and Boardman, 1995). Nevertheless, this assessment concerns currently tilled soils which are particularly susceptible to mechanical erosion, while precipitation at the beginning of the Holocene rose in extensively forested environments. SSY does not seem to have increased by more than $150 \%$ as a result of rising precipitation and erosion, taking all other environmental parameters as constant. SSY could have increased by at least $390 \%$, i.e. $75 \%$ of total increase, as a result of human activity during the final Neolithic, probably exacerbated by climate change. SSY increased more in SYp5 than SYp6, and less in SYp6 than SYp8, with a break in the intensity of erosion during the final Neolithic, which is a little earlier than the break observed by Miras et al. (2004) in the higher Massif Central. As there are few final Neolithic sites at Sarliève, this break could be a delayed effect of human settlement during the middle Neolithic, as observed elsewhere (Edwards and Whittington, 2001); forest cover was still abundant at this time and could have slow down the solid flux delivery to the palaeolake. Soil use changes during the Protohistorical and Historical periods do not seem to have significantly affected mechanical erosion intensity before the seventeenth century.

DSY increase during the late Holocene is more difficult to explain, as their rates are certainly strongly underestimated for the sub-Boreal and sub-Atlantic. Taking all other environmental parameters as constant, a $10 \%$ increase in water infiltration into the soil and a $1.5^{\circ} \mathrm{C}$ drop in the mean temperature at about $4500 \mathrm{yr}$ cal. BP could have led to an increase in chemical erosion (calcite dissolution) of less than $15 \%$. Thus, at least $90 \%$ of the DSY increase (overall 180\%) between SYp5 and SYp6 could also be anthropogenic, increased SSY reactivating DSY. The impact of climatic versus anthropogenic factors on SY during SYp5, a period characterized by very variable SSY and DSY rates and the development of ancient and middle Neolithic society, is currently being investigated.

From estimation of mean eroded soil thickness from SSY and DSY rates and duration of each SY phase, three distinct periods can be identified (Figure 12): (1) from the Bölling to the beginning of the Boreal (SYp1 to SYp3), total earth surface lowering in the catchment was about $20 \mathrm{~cm}$ thick; soil thickness was low as shown by relatively constant and low DSY/SSY ratio (\# 0.5) in environments marked by cold to cool and dry climate and sparse vegetation; (2) during the Boreal and Atlantic, during which erosion rates were probably still close to SY rates, total erosion was low $(8 \mathrm{~cm}$ thick) with rise in soil thickness shown by high DSY/SSY ratio (up to 1.5) as a result of vegetation cover growth and warmer climate, although the lower ratios during SYp5 could indicate the beginning of anthropogenic impact; (3) during the sub-Boreal and 


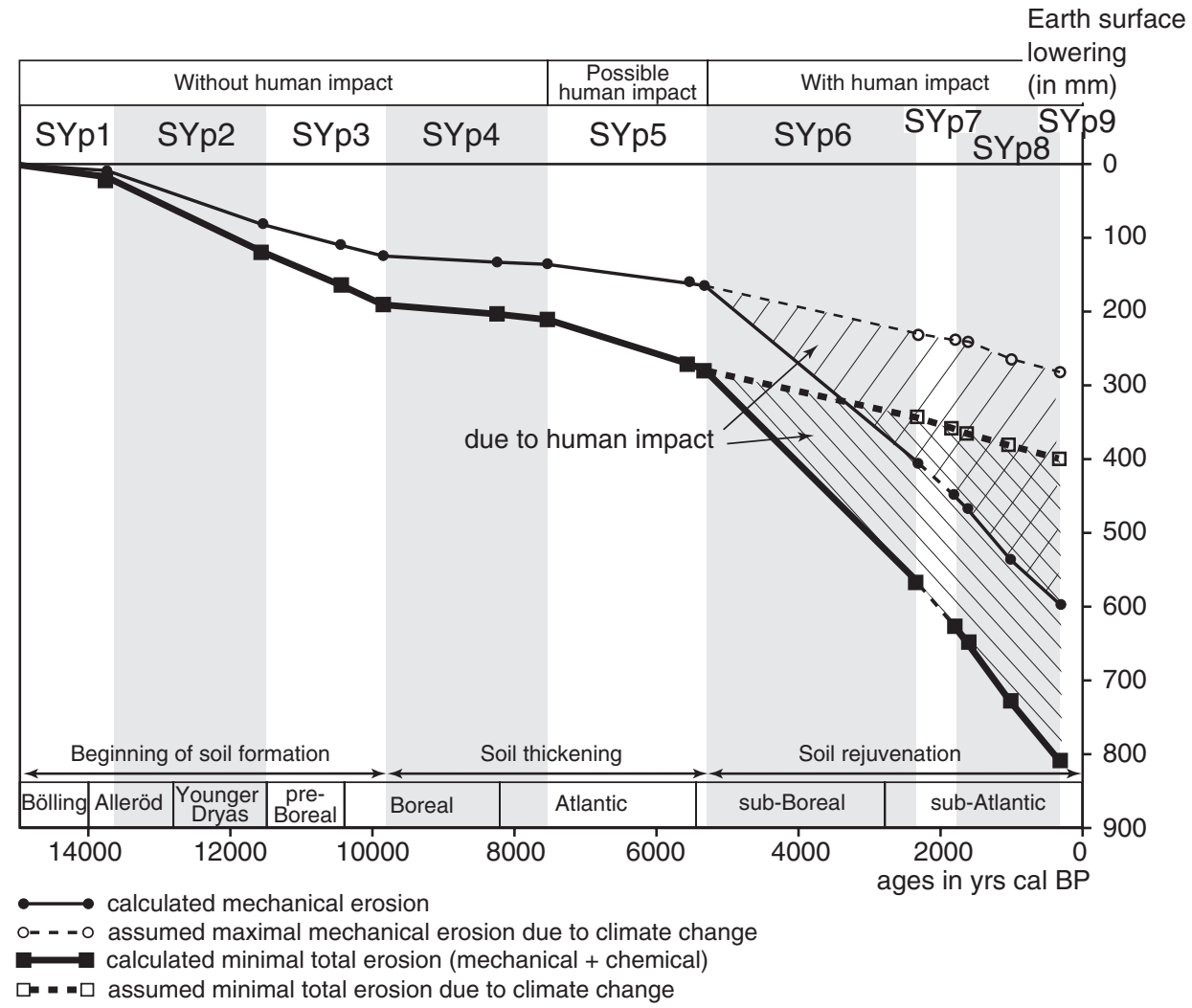

Figure 12. Evaluation of earth surface lowering and soil thickness from sediment yield rates since the Lateglacial

sub-Atlantic, soil erosion rates were much higher than SY rates: total erosion greatly increased ( $55 \mathrm{~cm}$ thick at least) with extensive soil rejuvenation and thinning characterized by a pronounced lowering of the DSY/SSY ratio (\# 0.25). This trend appears to be a consequence of human activity which is assumed to have accounted for more than $75 \%$ of SSY and $90 \%$ of DSY, compared with SY rates resulting only from climate during the late Holocene.

\section{Conclusion}

By quantifying stored sediment mass in the Sarliève palaeolake it was possible to calculate minimum solid (SSY) and dissolved (DSY) sediment yield rates for seven phases (SYp1 to SYp6 and SYp8) between about $15000 \mathrm{yr}$ cal. BP and $300 \mathrm{yr}$ cal. BP; phases SYp7 and SYp9 were marked by anthropogenic drying of the lake and lack of sediment stores. During the Lateglacial and early Holocene up to $7500 \mathrm{yr}$ cal. BP, SSY and DSY rates, lower on average than later, varied mainly in relation to climate change: higher rates (SYp2 and SYp3) correspond to colder periods (Younger Dryas and Preboreal), while lower rates (SYp1 and SYp4) correspond to periods of warmer climate (Bölling-Alleröd and Boreal). However, CF1 tephra fallout at $13700 \mathrm{yr}$ cal. BP induced greater SY during the Alleröd. After $7500 \mathrm{yr}$ cal. BP, the middle and late Holocene are marked by a sharp increase in SSY and DSY, reaching a peak during the final Neolithic after $5300 \mathrm{yr}$ cal. BP. Comparison of SY rates with quantified data of human settlement, and palaeoclimatic and palynological data, indicates that after $5300 \mathrm{yr}$ cal. BP, when the climate became cooler and more humid, at least $75 \%$ of SSY increase and more than $90 \%$ of DSY increase were due to human activities. Changes in soil use during the Protohistoric Times (SYp6) and the Historic Times up to the seventeenth century (SYp8) did not significantly alter SYrates. Extensive vegetation clearing due to climate change during the Younger Dryas and to human activity during the Historic Times can explain periods of severe mechanical erosion at some places (delivery of coarse-grained deltaic sediments) during SYp2 and SYp8. Catchment-soil evolution deduced from DSY and SSY rates and DSY/SSY ratio indicate that soils began to be formed during the Lateglacial and Preboreal, then thickened considerably during the Boreal and Atlantic, and finally became thinner (rejuvenation) mainly as the result of humaninduced erosion during the sub-Boreal and sub-Atlantic. Severe mechanical erosion during the late Holocene induced a sharp rise in chemical erosion, which was favoured by the presence of mainly carbonated rocks in the catchment.

\section{Acknowledgments}

This work was supported by the French CNRS-INSU ECLIPSE programs 'Interactions activités humaines - production et stockage de sédiments à l'Holocène en plaine et en moyenne montagne' and Zone Atelier Loire. We thank J.P. Bakyono, I. Pène and many other collaborators for their help in acquiring field data and sediment analysis, and the Institut National de Recherche d'Archéologie Préventive (INRAP) and the Society Fondasol Auvergne for their collaboration. We thank Miss Yates for their assistance in translation of this text and two anonymous reviewers for their constructive comments.

\section{References}

Aaby, B. 1976: Cyclic climatic variations in climate over the past $5,500 \mathrm{yr}$ reflected in raised bogs. Nature 263, 281-84. 
Alley, R.B. and Agustsdottir, A.M. 2005: The 8ka event: cause and consequences of a major Holocene abrupt climate change. Quaternary Science Reviews 24, 1123-49.

Anderson, D.E. 1997: Younger Dryas research and its implications for understanding abrupt climatic change. Progress in Physical Geography 21, 230-49.

Andrews, J.E. 2006: Palaeoclimatic records from stable isotopes in riverine tufas: Synthesis and review. Earth-Science Reviews 75, 85-104.

Antoine, P. and Fabre, D. 1980: Géologie appliquée au génie civil. Masson éd., Paris, 291 pp.

Argant, J. and Lopez-Saez, J.-A. 2004: L'occupation humaine du bassin de Sarliève depuis le Néolithique d'après la palynologie et l'étude des microfossiles non polliniques. 5e Rencontres méridionales de Préhistoire récente Auvergne et Midi, Actes de la cinquième session, Clermont-Ferrand, et 9 novembre 2002, Préhistoire du Sud-ouest. Suppl. 9, 25-34.

Ballut, C. 2000: Evolution environnementale de la Limagne de Clermont-Ferrand au cours de la seconde moitié de l'Holocène (Massif central français). PhD thesis, University Blaise Pascal of Clermont-Ferrand, $315 \mathrm{pp}$.

Barber, K.E., Chambers, F.M., Maddy, D., Stoneman, R. and Brew, J.S. 1994: A sensitive high-resolution record of late Holocene climatic change from a raised bog in northern England. The Holocene 4, 198-205.

Berner, E.K. and Berner, R.A. 1987: The global water cycle. PrenticeHall, Inc., 397 pp.

Bichet, V., Campy, M., Buoncristiani, J.F., Di-Giovanni, C., Meybeck, M. and Richard, H. 1999: Variations in sediment yield from the Upper Doubs River carbonate watershed (Jura, France) since the Late-Glacial Period. Quaternary Research 51, 267-79.

Boardman, J. 1990: Soil erosion on the South Downs: a review. In Boardman, J., Foster, I.D.L. and Dearing, J.A., editors, Soil erosion on agricultural land. Wiley, 87-105.

Boivin, P., Besson, J.C., Briot, D., Camus, G., de Goër de Herve, A., Gourgaud, A., Labazuy, P., de Larouzière, F.D., Livet, M., Mergoil, J., Miallier, D., Morel, J.M., Vernet, G. and Vincent, P.M. 2004: Volcanologie de la Chaîne de Puys. Ed. Parc Régional des Volcans d'Auvergne, 179 pp.

Bond, G., Kromer, B., Muscheler, R., Evans, M.N., Showers, W., Hoffmann, S., Lotti-Bond, R., Hajdas, I. and Bonani, G. 2001: Persistent solar influence on North Atlantic climate during the Holocene. Science 294, 2130-36.

Bréhéret, J.G., Macaire, J.J., Fleury, A., Fourmont, A. and SouliéMarsche, I. 2003: Indices de confinement dans les dépôts lacustres holocènes de Sarliève (Limagne, France). Comptes Rendus Géosciences 335, 479-85.

Bréhéret, J.G., Fourmont, A., Macaire, J.J. and Négrel, Ph. 2008: Microbially mediated carbonates in the Holocene lacustrine deposits from Sarliève, a small ancient lake of the French Massif Central, testify to the evolution of a restricted environment. Sedimentology 55, 557-78.

Brune, G.M. 1953: Trap efficiency of reservoirs. American Geophysical Union Transactions 34, 407-18.

Bullock, P. 1991: Soils. In United Kingdom Climate Change Impacts Review Group, editors, The potential effects of climate change in the United Kingdom. HMSO, 15-25.

Campy, M., Bichet, V., Di-Giovanni, C., Richard, H., Richard, J. and Olive, P. 1994: Evolution des flux de matière depuis 12000 ans dans la haute vallée du Doubs (France). Bulletin de la Societe Géologique de France 165, 381-400.
Carrion, J.S. 2002: Patterns and processes of Late Quaternary environmental change in a montane region of southwestern Europe. Quaternary Science Reviews 2, 2047-66.

Carson, M.A. and Kirkby, M.J. 1972: Hillslope form and process. Cambridge University Press, 475 pp.

Cerdan, O., Poesen, J., Govers, G., Saby, N., Le Bissonnais, Y., Gobin, A., Vacca, A., Quinton, J., Auerswald, K., Klik, A., Kwaad, F.J.P.M. and Roxo, M.J. 2006: Sheet and rill erosion. Chapter 2.4. In Boardman, J.and Poesen, J., editors, Soil erosion in Europe. Wiley, 501-13.

Chorley, R., Schumm, S.A. and Sugden, D. 1984: Geomorphology. Methuen, $689 \mathrm{pp}$.

Church, M. and Ryder, J.M. 1972: Paraglacial sedimentation: a consideration of fluvial processes conditioned by glaciation. Geological Society of America Bulletin 83, 3059-72.

Collins, B.D. and Dunne, T. 1986: Erosion of tephra from the 1980 eruption of Mount St. Helens. Geological Society of America Bulletin 97, 896-905.

Davis, B.A.S., Brewer, S., Stevenson, A.C., Guiot, J. and Data Contributors 2003: The temperature of Europe during the Holocene reconstructed from pollen data. Quaternary Science Reviews 22, 1701-16.

Dearing, J.A. and Jones, R.T. 2003: Coupling temporal and spatial dimensions of global sediment flux through lake and marine sediment records. Global and Planetary Change 39, 147-68.

de Beaulieu, J.L., Pons, A. and Reille, M. 1988: Histoire de la flore et de la végétation du Massif Central (France) depuis la fin de la dernière glaciation. Cahier de Micropaléontologie 3, 5-36.

Douglas, I. 1967: Man, vegetation and the sediment yields of rivers. Nature 215, 925-28.

Douglas, R., Gonzalez-Yajimovich, O., Ledesma-Vazquez, J. and Staines-Urias, F. 2007: Climate forcing, primary production and the distribution of Holocene biogenic sediments in the Gulf of California. Quaternary Science Reviews 26, 115-29.

Edwards, K.J. and Whittington, G. 2001: Lake sediments, erosion and landscape change during the Holocene in Britain and Ireland. Catena 42, 143-73.

Einsele, G. and Hinderer, M. 1998: Quantifying denudation and sediment-accumulation systems (open and closed lakes): basic concepts and first results. Palaeogeography, Palaeoclimatology, Palaeoecology 140, 7-21.

Favis-Mortlock, D. and Boardman, J. 1995: Nonlinear responses of soil erosion to climate change: a modelling study on the UK South Downs. Catena 25, 365-87.

Fourmont, A. 2005: Quantification de l'érosion et de la sédimentation dans le bassin de Sarliève (Massif central, France) au Tardiglaciaire et à l'Holocène. Impact des facteurs naturels et anthropiques. PhD thesis, University of Tours, $419 \mathrm{pp}$.

Fourmont, A., Macaire, J.-J., Bréhéret, J.-G., Argant, J., Prat, B. and Vernet, G. 2006: Tephras in lacustrine sediments of the Sarliève marsh (French Massif Central): age and preservation. Comptes Rendus Géosciences 338, 1141-49.

Fourmont, A., Macaire, J.-J. and Bréhéret J.-G. 2009: Contrasted late glacial and Holocene hydrology of Sarlieve paleolake (France) from sediment geometry and detrital vs. biochemical composition. Journal of Paleolimnology 41, 471-90.

Fournier, G. 1996: Sarliève: un lac au moyen âge. Association du Site de Gergovie 11, 2-34.

Gabet, E.J. and Mudd, S.M. 2009: A theoretical model coupling chemical weathering rates with denudation rates. Geology 37, 151-54. 
Gachon, L. 1963: Contribution à l'étude du quaternaire récent de la Grande Limagne marno-calcaire: morphogenèse et pédogenèse. Annales agronomiques 14, 191 pp.

Gay, I. and Macaire, J.-J. 1999: Estimation des taux d'érosion chimique tardiglaciaires et holocènes par la méthode des bilans d'altération. Application au bassin du lac Chambon (Massif Central, France). Comptes Rendus de l'Academie de Science Paris 328, 387-92.

Georjon, C., Jallet, F., Lagrue, A. and Loison, G. 2004: Le Néolithique ancien et moyen en Auvergne: bilan et perspectives à la lumière des données récentes. Actes des Ve Rencontres méridionales de Préhistoire récente, Clermont-Ferrand (8-9 novembre 2002). Préhistoire du Sud-Ouest. Suppl. 9, 107-32.

Goeury, C. and de Beaulieu, J.L. 1979: A propos de la concentration du pollen à l'aide de la liqueur de Thoulet dans les sédiments minéraux. Pollens et spores 30, 73-89.

Gombert, P. 1997: Quantification du rôle des paramètres climatiques dans la dissolution karstique. Comptes Rendus de l'Academie de Science Paris 324, 17-23.

Guiot, J., Pons, A., de Beaulieu, J.L. and Reille, M. 1989: A 140,000year continental climate reconstruction from two European pollen records. Nature 338, 309-13.

Heineman, H.G. 1984: Reservoir trap efficiency. In Hadley, R.F. and Walling, D.E., editors, Erosion and sediment yield: some methods of meseasurement and modelling. Geo Books, 201-18.

Hinderer, M. 2001: Late Quaternary denudation of the Alps, valley and lake fillings and modern river loads. Geodinamica Acta 14, 231-63.

Hinschberger, F., Fourmont, A., Macaire, J.-J., Bréhéret, J.-G., Guérin, R. and Bakyono, J.P. 2006: Contribution of geophysical surveys to the study of fine grained lacustrine sediments. Application to the Sarliève marsh (Massif Central, France) Bulletin de la Societe Géologique de France 177, 311-22.

Hooke, R.L. 2000: On the history of humans as geomorphic agents. Geology 28, 843-46.

Jeambrun, M., Aubert, M., Bouiller, R., Camus, G., Cochet, A., d'Arcy, D., Giot, D., Baudry, D., Roche, A. and Bonhommet, N. 1973: Carte géologique à 1/50000 de Clermont-Ferrand XXV-31 et notice. BRGM Ed.

Johnsen, S.J., Clausen, H.B., Dansgaard, W., Fuhrer, K., Gundestrup, N.S., Hammer, C.U., Iversen, P., Jouzel, J., Stauffer, B. and Steffensen, J.P. 1992: Irregular glacial interstadials recorded in a new Greenland ice core. Nature 359, 311-13.

Johnsen, S.J., Dahl-Jensen, D., Gundestrup, N., Steffensen, J.P., Clausen, H.B., Miller, H., Masson-Delmotte, V., Sveinbjörndottir, A.E. and White, J. 2001: Oxygene isotope and paleotemperature records from six Greenland ice-core stations: Camp Century, Dye-3, GRIP, GISP2, Renland and NorthGRIP. Journal of Quaternary Science 16, 299-307.

Judson, S. and Ritter, D.F. 1964: Rates of regional denudation in United States. Journal of Geophysical Research 69, 3395-401.

Kessler, J. and Chambraud, A. 1986: La météo de la France. Tous les climats localité par localité. Lattès.

Ludwig, W. and Probst, J.L. 1998: River sediment discharge to the oceans: present-day controls and global budgets. American Journal of Science 298, 265-95.

Macaire, J.-J., Bossuet, G., Choquier, A., Cocirta, C., De Luca, P., Dupis, A., Gay, I., Mathey, E. and Guenet, P. 1995: Effets climatique et anthropique sur l'érosion mécanique en montagne cristalline de région tempérée pendant le Tardiglaciaire et l'Holocène.
Un exemple, le bassin du Lac Chambon (Massif Central, France). Comptes Rendus de l'Academie de Science Paris 320, 579-85.

Macaire, J.-J., Bossuet, G., Choquier, A., Cocirta, C., De Luca, P., Dupis, A., Gay, I., Mathey, E. and Guenet, P. 1997: Sediment yield during Lateglacial and Holocene periods in the Lac Chambon watershed, Massif Central, France. Earth Surface Processes and Landforms 22, 473-89.

Macaire, J.-J., Bernard, J., Di-Giovanni, C., Hinschberger, F., Limondin-Lozouet, N. and Visset, L. 2006: Quantification and regulation of organic and mineral sedimentation in a Late Holocene floodplain as a result of climatic and human impacts (the Taligny marsh, Parisian Basin, France). The Holocene 16, 647-60.

Macklin, M.G., Benito, G., Gregory, K.J., Johnstone, E., Lewin, J., Michczynska, D.J., Soja, R., Starkel, L. and Thorndycraft, V.R. 2006: Past hydrological events reflected in the Holocene fluvial record of Europe. Catena 66, 145-54.

Magny, M. 2004: Holocene climate variability as reflected by mid-European lake-level fluctuations and its probable impact on prehistoric human settlements. Quaternary International $113,65-79$.

Magny, M., Leuzinger, U., Bortenschlager, S. and Haas, J.N. 2006: Tripartite climate reversal in central Europe 5600-5300 years ago at Arbon-Bleiche, Switzerland. Quaternary Research 65, 3-19.

Magny, M., Gauthier, E., Vannière, B. and Peyron, O. 2008: Palaeohydrological changes and human-impact history over the last millenium recorded at Lake Joux in the Jura Mountains, Switzerland. The Holocene 18, 255-65.

McNeil, J.D. 1980: Electromagnetic terrain conductivity measurements at low induction numbers. Technical note TN-6. Geonics, $15 \mathrm{pp}$.

Meybeck, M. 1979: Concentrations des eaux fluviales en éléments majeurs et apport en solution aux océans. Revue de Géologie Dynamique et de Géographie Physique 21, 215-45.

1987: Global chemical weathering of surficial rocks estimated from river dissolved loads. American Journal of Science 287, 401-28.

Milliman, J.D. and Meade, R.H. 1983: World-wide delivery of river sediment to the oceans. Journal of Geology 91, 1-21.

Milliman, J.D. and Syvitski, J.P.M. 1992: Geomorphic/tectonic control of sediment discharge to the ocean: the importance of small mountainous rivers. Journal of Geology 100, 525-44.

Miras, Y., Laggoun-Dégarge, F., Guenet, P. and Richard, H. 2004: Multi-disciplinary approach to changes in agro-pastoral activities since the Sub-Boreal in the surroundings of the "narse d'Espinasse' (Puy de Dôme, French Massif Central). Vegetation History and Archeobotany 13, 91-103.

Peteet, D. 1995: Global Younger Dryas? Quaternary International 28, 93-104.

Pimentel, D., Harvey, P., Resosudarmo, P., Sinclair, K., Kurz, D., McNair, M., Crist, S., Shpritz, L., Fitton, L., Saffouri, R. and Blair, R. 1995: Environmental and economic costs of soil erosion and conservation benefits. Science 267, 1117-23.

Pomel, M. 1853: Catalogue méthodique et descriptif des vertébrés fossiles découverts dans le bassin hydrographique supérieur de la Loire et surtout dans la vallée de son affluent principal, l'Allier. Annales scientifiques, littéraires et indusrielles de l'Auvergne XXVI, 81-229.

Pommerol, F. 1877: Existence de l'Homme en Auvergne à l'époque du renne et des volcans à cratères. Comptes rendus de l'Association 
Française pour l'Avancement des Sciences, 5ème session, 11ème section: Anthropologie, 661-68.

Pouenat, P. 2007: Un tesson Villeneuve-Saint-Germain dans un lot épicardial. Archéopages 19, 74-75.

Prat, B. 2006: Systèmes agropastoraux et milieux périurbains en Basse Auvergne au cours des trois derniers millénaires: contribution de l'analyse palynologique à l'étude des interactions sociétés-milieux. $\mathrm{PhD}$ thesis, University Blaise Pascal of Clermont II, $368 \mathrm{pp}$.

Ruddiman, W.F. 2003: The anthropogenic greenhouse era began thousands of years ago. Climatic Change 61, 261-93.

Trément, F., Argant, J., Bréhéret, J-G., Cabanis, M., Dousteyssier, B., Fourmont, A., Fournier, G., López Sáez, J.A., Macaire, J.-J., Prat, B. and Vernet, G. 2005: Paysages et peuplement dans le bassin de Sarliève du Néolithique au Moyen Âge (Puy-de-Dôme, France). Eléments pour un nouveau modèle socio-environnemental. In Temps et espaces de l'Homme en Société, analyses et modèles spatiaux en archéologie. Actes de la XXVème rencontre intern. d'archéologie et d'histoire d'Antibes, sous la dir. J.-F. Berger,F. Bertoncello, F. Braemer, G. Davtian, et M. Gazenbeek. APDCA, 485-98.

Trément, F., Loison, G., Argant, J., Bréhéret, J.-G., Cabanis, M., Dousteyssier, B., Fourmont, A., Fournier, G., Liabeuf, R., Lopez-Saez, J.-A., Macaire, J.-J., Milcent, P.-Y., Prat, B., Rialland, Y. and Vernet, G. 2006: Interactions sociétés-milieux en Grande Limagne du Néolithique à l'époque romaine. Apport des recherches interdisciplinaires conduites dans le bassin de Sarliève (Puy-de-Dôme). In Fouéré, P., Chevillot, C., Courtaud, P., Ferullo, O. and Leroyer, C., editors, Paysages et peuplements. Aspects culturels et chronologiques en France méridionale. Actualité de la recherche. Actes des VIe rencontres méridionales de Préhistoire récente (Périgueux, 14-16 octobre 2004), coédition ADRAHP-PSO, 11-32 (Préhistoire du SudOuest, 11e supplément).

Trément, F., Mennessier-Jouannet, C., Argant, J., Bréhéret, J.-G., Cabanis, M., Dousteyssier, B., Fourmont, A., Lopez-Saez, J.-A., Macaire, J.-J., Prat, B. and Vernet, G. 2007a: Le bassin de Sarliève: occupation du sol et paléo-environnement à l'Age du Fer. In Mennessier-Jouannet, C. and Deberge, Y., editors, L'archéologie de l'Age du Fer en Auvergne. Actes du XXVIIe colloque international de l'AFEAF (Clermont-Ferrand, 29 mai-1er juin 2003). Thème régional. Lattes, Monographies d'archéologie méditerranéenne, 385-400.
Trément, F., Argant, J., Bréhéret, J.-G., Cabanis, M., Dousteyssier, B., Fourmont, A., Fournier, G., Liabeuf, R., Loison, G., LópezSáez, J.-A., Macaire, J.-J., Marinval, P., Mennessier-Jouannet, C., Milcent, P.-Y., Prat, B., Rialland, Y. and Vernet, G. 2007b: Un ancien lac au pied de l'oppidum de Gergovie (Puy-deDôme): interactions sociétés-milieux dans le bassin de Sarliève à 1'Holocène. Gallia 64, 289-351.

Ursic, S.J. and Dendy, F.E. 1965: Sediment yield from small watersheds under various land uses and forest covers. In Proceedings, federal interagency sedimentation conference, 1963. US Department of Agriculture Miscellaneous Publication 970, $47-52$.

Valero-Garcés, B.L., Delgado-Huertas, A., Navas, A., Machin, J., Gonzales-Samperiz, P. and Kelts, K. 2000: Quaternary paleohydrological evolution of a playa lake: Salada Mediana,central Ebro Basin, Spain. Sedimentology 47, 1135-56.

van Geel, B., van der Plicht, J., Kilian, M.R., Klaver, E.R., Kouwenberg, J.H.M., Renssen, H., Reynaud-Farrera, I. and Waterbolk, H.T. 1998: The sharp rise of $\delta \mathrm{C} 14 \mathrm{ca} .800 \mathrm{cal}$ BC: possibles causes, related climatic teleconnections and the impact on human environments. Radiocarbon 40, 535 - 50.

Vernet, G. and Raynal, J.P. 2000: Un cadre téphrostratigraphque réactualisé pour la préhistoire tardiglaciaire et holocène de Limagne (Massif central, France). Comptes Rendus Academie des Sciences Paris 330, 399-405.

Vernet, G., Caillat, P., Mennessier-Jouannet, C., Parent, D., Rebiscoul, A., Richier, A., Seris, D., Vernet, B. and Wittmann, A. 2005: Rapport final d'opération de diagnostic et de fouille archéologique portant sur le bassin de Sarliève, Grande Halle d'Auvergne. INRAP, Direction interrégionale Rhône-Alpes/ Auvergne, Centre archéologique régional d'Auvergne, 3 vol.

Von Grafenstein, U., Erlenkeuser, H., Brauer, A., Jouzel, J. and Johnsen, S.J. 1999: A mid-European decadal isotope-climate record from 15,500 to 5000 years BP. Science 284, 1654-57.

Walling, D.E. and Webb, B.W. 1986: Solutes in river systems. In Trudgill, S.T., editor, Solute processes. Wiley, 251-327.

Wilkinson, B.H. 2005: Humans as geologic agents: a deep-time perspective. Geology 33, 161-64.

Zolitschka, B. 1998: A 14,000 year sediment yield record from western Germany based on annually laminated lake sediments. Geomorphology 22, 1-17. 